\title{
Remote-Handled Low- Level Waste Disposal Project Alternatives Analysis
}

Lisa Harvego

Brady Orchard Joan Connolly Margaret Hinman Charles Marcinkiewicz

October 2009

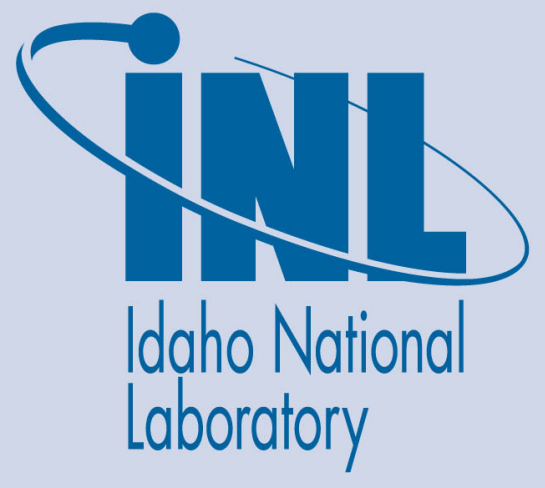

The INL is a U.S. Department of Energy National Laboratory operated by Battelle Energy Alliance 
INL/EXT-09-17152

\title{
Remote-Handled Low-Level Waste Disposal Project Alternatives Analysis
}

${ }^{1}$ North Wind, Inc.

\author{
Lisa Harvego \\ Brady Orchard \\ Joan Connolly ${ }^{1}$ \\ Margaret Hinman ${ }^{1}$ \\ Charles Marcinkiewicz ${ }^{1}$
}

October 2009

Idaho National Laboratory
Idaho Falls, Idaho 83415

http://www.inl.gov

Prepared for the

U.S. Department of Energy

Office of Nuclear Energy

Under DOE Idaho Operations Office

Contract DE-AC07-05ID14517 


\begin{abstract}
This report identifies and compares onsite and offsite disposal alternatives for the disposal of remote-handled low-level waste generated by the Idaho National Laboratory and its tenants.

Each alternative addresses the disposal path for all remote-handled lowlevel waste types over the period of interest. The alternatives are compared using cost, risk, and complexity discriminators to arrive at a recommended approach. Schedule alignment with disposal needs is addressed to ensure that all waste types are managed appropriately.
\end{abstract}

The recommended alternative for disposal of remote-handled low-level waste based on this analysis is to build a disposal facility at the Idaho National Laboratory Site. 


\section{EXECUTIVE SUMMARY}

This report presents an analysis of alternatives for disposal of remote-handled low-level waste (LLW) generated by the Idaho National Laboratory (INL) and its tenants, the Office of Nuclear Energy and the Office of Naval Reactors. The contents of this report will support decision-making and planning activities for future remote-handled LLW disposal. A systematic approach has been used to identify disposal needs, alternatives for meeting those needs, and to develop the associated costs, schedules, and risks in sufficient detail to a make valid comparison of the alternatives.

The INL Site routinely generates contact-handled and remote-handled LLW from facility operations and decontamination and decommissioning of inactive facilities. Historically, INL has disposed of its LLW in a disposal facility located at the Radioactive Waste Management Complex. This facility includes disposal pits and concrete vaults. In 2006, INL began planning for anticipated closure of this onsite disposal facility upon closure of the Radioactive Waste Management Complex and conducted a study of onsite and offsite disposal options. The INL study determined that the contact-handled LLW generated at the INL Site meets the waste acceptance criteria for offsite disposal sites and could be shipped using existing commercial containers (INL 2006). Disposal of LLW in the disposal pit ceased on September 30,2008, and the offsite option has been selected and is being implemented for all contact-handled LLW and for the portion of the remote-handled LLW that had been disposed of in the pit. However, because of the presence of certain radionuclides and high radiation levels, remote-handled LLW activated metals and ion-exchange resins can present unique challenges for shipping offsite, both in terms of packaging and shipping and acceptance by offsite disposal sites. The 2006 analysis identified the capabilities that would need to be developed to dispose of remote-handled LLW, under an offsite or onsite disposal alternative.

On July 1, 2009, the Department of Energy approved a mission need statement for the INL Remote-Handled LLW Disposal Project to develop replacement remote-handled low-level waste disposal capability by the end of Fiscal Year 2015 to support cost-effective, efficient operations in support of INL's nuclear energy mission and the Naval Nuclear Propulsion Program. Such disposal capability is required to enhance departmental and national mission-based research, defense, and energy programs (DOE 2009a). The mission need statement identified the following range of alternatives:

- $\quad$ Continued disposal at the Radioactive Waste Management Complex

- Disposal at the Idaho Comprehensive Environmental Response, Compensation, and Liability Act Disposal Facility

- Interim storage

- $\quad$ Storage for decay

- Development of an onsite remote-handled LLW disposal facility

- $\quad$ Offsite remote-handled LLW disposal (multiple locations)

- Privatization of remote-handled LLW disposal

- No action. 
After screening for viability, the alternatives presented for further analysis in this report are as follows:

- All remote-handled LLW disposed of onsite in a new facility

- $\quad$ All remote-handled LLW disposed of offsite at the Nevada Test Site.

These alternatives are assessed for cost, risk, and complexity. The recommended alternative is disposal of all remote-handled LLW onsite. This alternative has the lowest cost and involves the least amount of upfront investment. It is the lowest risk because it presents no offsite transportation or disposal considerations. It also is the least complex because coordination with and reliance on an offsite disposal facility is not required. 


\section{CONTENTS}

ABSTRACT iii

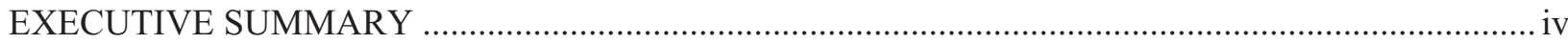

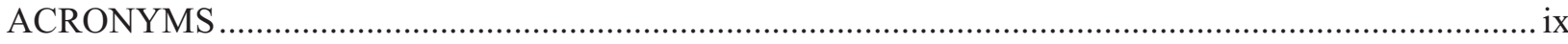

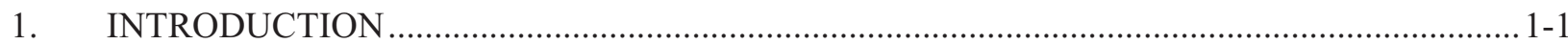

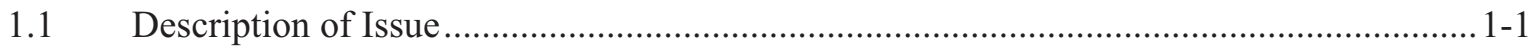

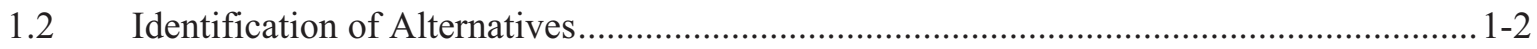

1.3 General Assumptions and Approach to Alternatives Analysis....................................... 1-3

2. IDAHO NATIONAL LABORATORY REMOTE-HANDLED LOW-LEVEL WASTE STREAMS2-1

2.1 Remote-Handled Low-Level Waste Types and Volume Expected through 2035............2-1

2.1.1 Remote-Handled Low-Level Waste Generation Rates ....................................2-1

2.1.2 General Characteristics of Remote-Handled Low-Level Waste Packaging..... 2-2

3. OFFSITE ALTERNATIVE FOR REMOTE-HANDLED LOW-LEVEL WASTE DISPOSAL ....3-1

3.1 Selection of Offsite Facilities for Evaluation .............................................................. 3-1

3.1.1 Candidate Facility Descriptions .............................................................. $3-1$

3.1.2 Candidate Facility Screening …….............................................................

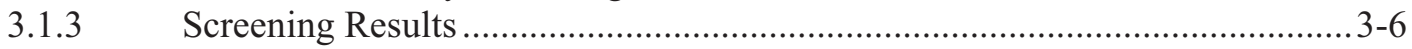

3.2 Analysis of Offsite Disposal of Remote-Handled Low-Level Waste .............................. 3-6

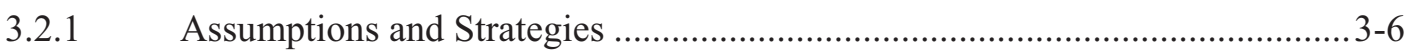

3.2.2 Shipping Considerations and Assumptions ................................................... 3-6

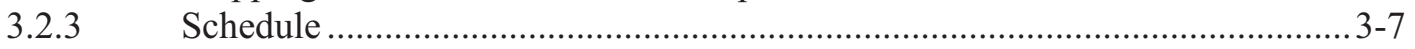

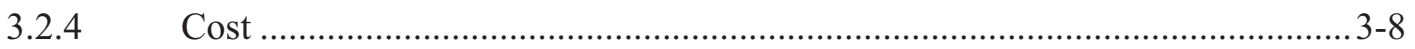

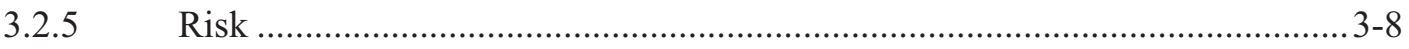

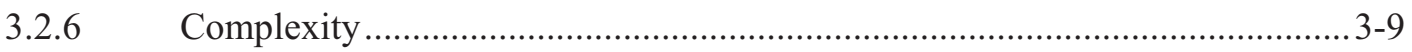

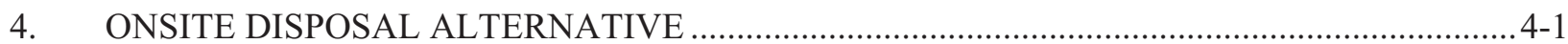

4.1 Siting and Design Considerations for Onsite Disposal of Idaho National Laboratory

Remote-Handled Low-Level Waste .............................................................................. 4-1

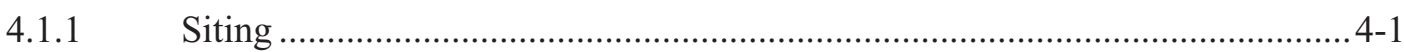

4.1.2 Disposal Facility Description/Waste Acceptance Criteria ............................. 4-2

4.2 Analysis of Onsite Disposal of All Remote-Handled Low-Level Waste ......................... 4-3

4.2.1 Assumptions and Strategies .................................................................. $4-3$ 


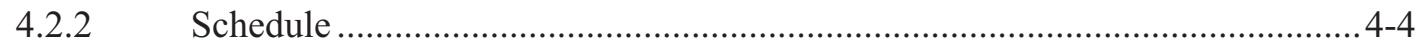

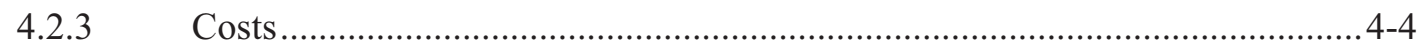

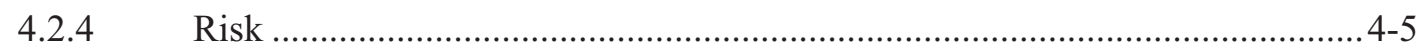

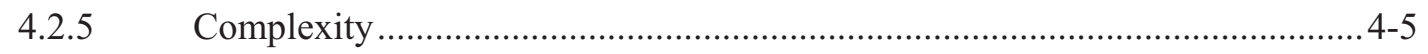

5. REMOTE-HANDLED LOW-LEVEL WASTE DISPOSAL ALTERNATIVE EVALUATION...5-1

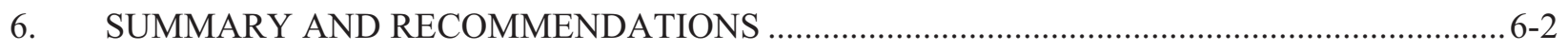

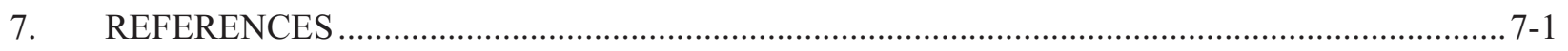

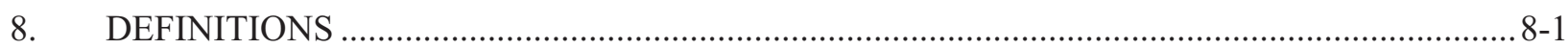

\section{APPENDIXES}

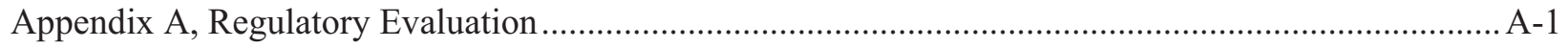

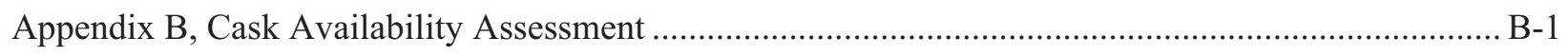

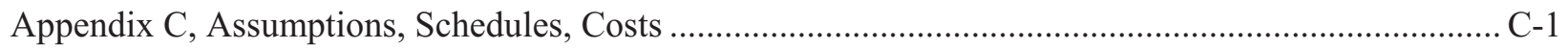

\section{FIGURES}

3-1. Schedule for offsite disposal activities for remote-handled low-level waste resins and activated metals using truck-loaded casks ...........................................................................

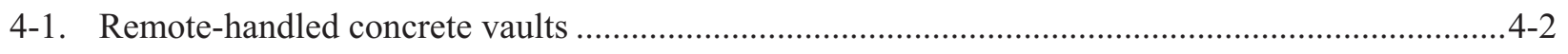

4-2. Remote-handled low-level waste disposal onsite ....................................................................

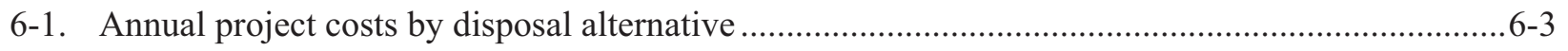

\section{TABLES}

1-1. Summary of screening results of remote-handled low-level waste disposal alternatives for

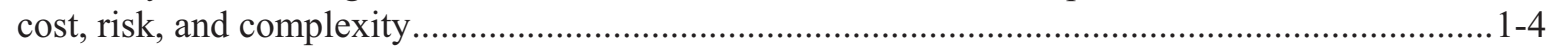

1-2. Options considered for low-level waste disposal ................................................................. 1-5

2-1. Remote-handled low-level waste debris, resins, and activated metals waste streams ...................2-1

2-2. Waste anticipated to be generated for each remote-handled low-level waste at the Idaho National Laboratory Site

3-1. Disposal facility screening: waste acceptance criteria compliance and availability relative to low-level waste types ${ }^{\mathrm{a}}$.....

5-1. Ranking of alternatives for Idaho National Laboratory remote-handled low-level waste disposal capability 


\section{ACRONYMS}

ATR

CERCLA

CFR

DOE

EA

EIS

EMWMF

FY

ICDF

INL

LLW

LLWRA

LLRWPAA

MFC

NEPA

NNSA

NRC

NRF

NTS

$\mathrm{NuPac}$

RWMC

SDA

WAC
Advanced Test Reactor

Comprehensive Environmental Response, Compensation and Liability Act

Code of Federal Regulations

U.S. Department of Energy

environmental assessment

environmental impact statement

Environmental Management Waste Management Facility

fiscal year

Idaho CERCLA Disposal Facility

Idaho National Laboratory

low-level waste

low-level radioactive waste

Low-level Radioactive Waste Policy Amendments Act

Materials and Fuels Complex

National Environmental Policy Act

National Nuclear Security Administration

Nuclear Regulatory Commission

Naval Reactors Facility

Nevada Test Site

Nuclear Packaging

Radioactive Waste Management Complex

Subsurface Disposal Area

waste acceptance criteria 


\section{Remote-Handled Low-Level Waste Disposal Project Alternatives Analysis}

\section{INTRODUCTION}

This report presents an analysis of the alternatives for disposal of remote-handled low-level waste (LLW) generated by the Idaho National Laboratory (INL) and its tenants, the Office of Nuclear Energy and the Office of Naval Reactors. A systematic approach has been used to identify disposal needs, alternatives for meeting those needs, and to develop the associated costs, schedules, and risks in sufficient detail to a make valid comparison of the alternatives. This report has been prepared to support project planning under U.S. Department of Energy (DOE) Oder 413.3A, "Program and Project Management for Acquisition of Capital Assets."

\subsection{Description of Issue}

The INL routinely generates contact-handled and remote-handled LLW from facility operations and decontamination and decommissioning of inactive facilities. Historically, INL has disposed of its LLW in the Subsurface Disposal Area (SDA) of the Radioactive Waste Management Complex (RWMC). This facility includes disposal pits and concrete vaults. In 2006, INL began planning for anticipated closure of this onsite disposal facility upon closure of RWMC and conducted a study of onsite and offsite disposal options. The INL study determined that contact-handled LLW generated at the INL site meets the waste acceptance criteria (WAC) for offsite disposal sites and could be shipped using existing commercial containers (INL 2006). Disposal of LLW in the SDA pit ceased on September 30, 2008, and the offsite option has been selected and is being implemented for the contact-handled LLW and for the portion of the remote-handled LLW that had been disposed of in the pits. However, because of the presence of certain radionuclides and high radiation levels, remote-handled LLW activated metals and ion-exchange resins can present unique challenges for shipping offsite, both in terms of packaging and shipping and acceptance by offsite disposal sites. The 2006 analysis identified a need for a project to develop capabilities to dispose of remote-handled LLW, under an offsite or onsite disposal scenario.

On July 1, 2009, DOE approved a mission need statement for the INL Remote-Handled LLW Disposal Project to develop replacement remote-handled low-level waste disposal capability by the end of Fiscal Year (FY) 2015. This will support cost-effective, efficient operations in support of INL's nuclear energy mission and the Naval Nuclear Propulsion Program. Such disposal capability is required to enhance departmental and national mission-based research, defense, and energy programs (DOE 2009a).

This alternatives analysis was conducted to implement project planning requirements of DOE Order 413.3A for conceptual design. The objective of this alternatives analysis is to provide an alternative for future remote-handled LLW disposal that will form the basis for the conceptual design to be submitted for Critical Decision-1 approval. A systematic approach was employed to achieve this objective, which involved defining future remote-handled LLW disposal needs, evaluating options and disposal alternatives for remote-handled LLW, and recommending an alternative.

The DOE manual for implementing DOE Order 435.1, "Radioactive Waste Management," provides DOE's policy for disposing of radioactive waste, including LLW:

DOE radioactive waste shall be treated, stored, and in the case of low-level waste, disposed of at the site where the waste is generated, if practical; or at another DOE facility. If DOE capabilities are not practical or cost effective, 
exemptions may be approved to allow use of non-DOE facilities for the storage, treatment, or disposal of DOE radioactive waste.

Recent DOE guidance has reinforced this policy, noting that, if feasible, disposal should occur at the facility where LLW is generated. If onsite disposal is not feasible, use of a federal disposal facility is preferred, although a commercial facility could be used on an exemption basis when it is demonstrated to be compliant, cost-effective, and in the best interest of DOE (DOE 2009).

This document includes the analysis that is needed to implement DOE policy. It addresses remote-handled LLW disposal needs after October 1, 2015. It does not include mixed low-level waste, which DOE has determined will not be disposed of onsite (DOE 2000). The LLW identified for planning purposes includes waste expected to be generated from ongoing operations for 20 years, in addition to a contingency to account for future missions.

\subsection{Identification of Alternatives}

In the mission need statement for the project (DOE 2009a), a range of alternatives were considered for INL remote-handled LLW disposal activities and are listed as follows:

- $\quad$ Continued disposal at RWMC

- $\quad$ Disposal at the Idaho Comprehensive Environmental Response, Compensation and Liability Act (CERCLA) Disposal Facility (ICDF)

- Interim storage

- $\quad$ Storage for decay

- $\quad$ Development of an onsite remote-handled LLW disposal facility

- $\quad$ Offsite remote-handled LLW disposal (multiple locations)

- $\quad$ Privatization of remote-handled LLW disposal

- No action.

In the first step of the alternatives analysis, each alternative identified in the mission need statement was screened for viability in terms of meeting the mission need. This section describes the screening process that led to selection of alternatives for further analysis.

The alternative of continued disposal at RWMC was identified in the mission need statement. This alternative is not part of current plans for RWMC. RWMC is planned for closure pursuant to INL's Federal Facility Agreement/Consent Order for cleanup of the site. Disposal in concrete disposal vaults at RWMC will continue until the facility is full or until it must be closed in preparation for final remediation of the SDA (approximately at the end of FY 2015). Implementation of the RWMC record of decision for cleanup is not likely to impact remote-handled LLW disposal prior to September 30, 2012; however, it may impact remote-handled LLW disposal prior to the end of FY 2015. The Office of Environmental Management contractor will implement the record of decision in a manner that supports operation of the remote-handled LLW disposal vaults through the end of FY 2015, if possible, subject to the provisions of the record of decision. Therefore, disposal at RWMC past the year 2015 is not a viable alternative for 
providing remote-handled LLW disposal capacity; this alternative was screened from further consideration.

Use of ICDF for remote-handled LLW disposal was identified in the mission need statement. ICDF is a land disposal facility authorized by the U.S. Environmental Protection Agency and the Idaho Department of Environmental Quality that is used to dispose of LLW and mixed (radioactive and hazardous) waste generated from remedial activities at INL. ICDF is limited to receipt of CERCLA waste, and approval would be needed from the U.S. Environmental Protection Agency and the State of Idaho to allow acceptance of waste from ongoing operations. ICDF has two lined disposal cells but does not include vaults for disposal of remote-handled activated metals and resins. Therefore, new construction in the form of remote-handled LLW vaults would be required to implement disposal at ICDF. Given this construction requirement, the possible expansion of ICDF is included within the alternative of onsite disposal at a new facility and will not be analyzed separately.

Two alternatives in the mission need statement (i.e., interim storage and storage for decay) are effective strategies if disposal capacity is unavailable. However, these alternatives would not fulfill the need for final disposal capacity for the remote-handled LLW expected to be generated; therefore, they were screened from further analysis.

The alternative of privatization of INL remote-handled LLW disposal was identified in the mission need statement. A private facility for disposal of radioactive waste would be licensed by the Nuclear Regulatory Commission (NRC) instead of being regulated by DOE. Privatization offers a means by which disposal alternatives can be implemented, but it will not be considered as a separate alternative for attaining remote-handled LLW disposal capability.

Based on this screening, the following two primary alternatives are considered potentially viable in establishing continued, uninterrupted remote-handled LLW disposal capability for INL and its tenants:

- Design, construction, and operation of a new onsite remote-handled LLW disposal facility

- $\quad$ Disposal of remote-handled LLW at an offsite facility, with the Nevada Test Site (NTS) serving as the base case costing scenario.

These alternatives will be the primary alternatives considered in this analysis as the means for achieving the mission need for remote-handled LLW disposal capacity for INL. The screening process used to identify the viable alternatives is summarized in Table 1-1.

\subsection{General Assumptions and Approach to Alternatives Analysis}

A systematic approach was used to fully assess the viable remote-handled LLW management alternatives and accomplish the objectives of this analysis. Regulatory requirements and considerations for disposal were identified (see Appendix A). The waste expected to be generated was inventoried, categorized, and evaluated against the WAC of existing offsite DOE and commercial disposal facilities. Viable facilities were identified, including a new onsite facility. For these facilities, shipping, packaging, and infrastructure needs were evaluated in order to establish schedules, costs, and risk. The options considered are summarized in Table 1-2. Alternatives were then developed that represent pathways to accomplish disposition of all INL Site remote-handled LLW through at least the year 2035. These alternatives were evaluated and compared based on cost, risk, and complexity discriminators. This comparison forms the basis for recommendations and identification of the critical next steps required to pursue the recommendations. 
Table 1-1. Summary of screening results of remote-handled low-level waste disposal alternatives for cost, risk, and complexity.

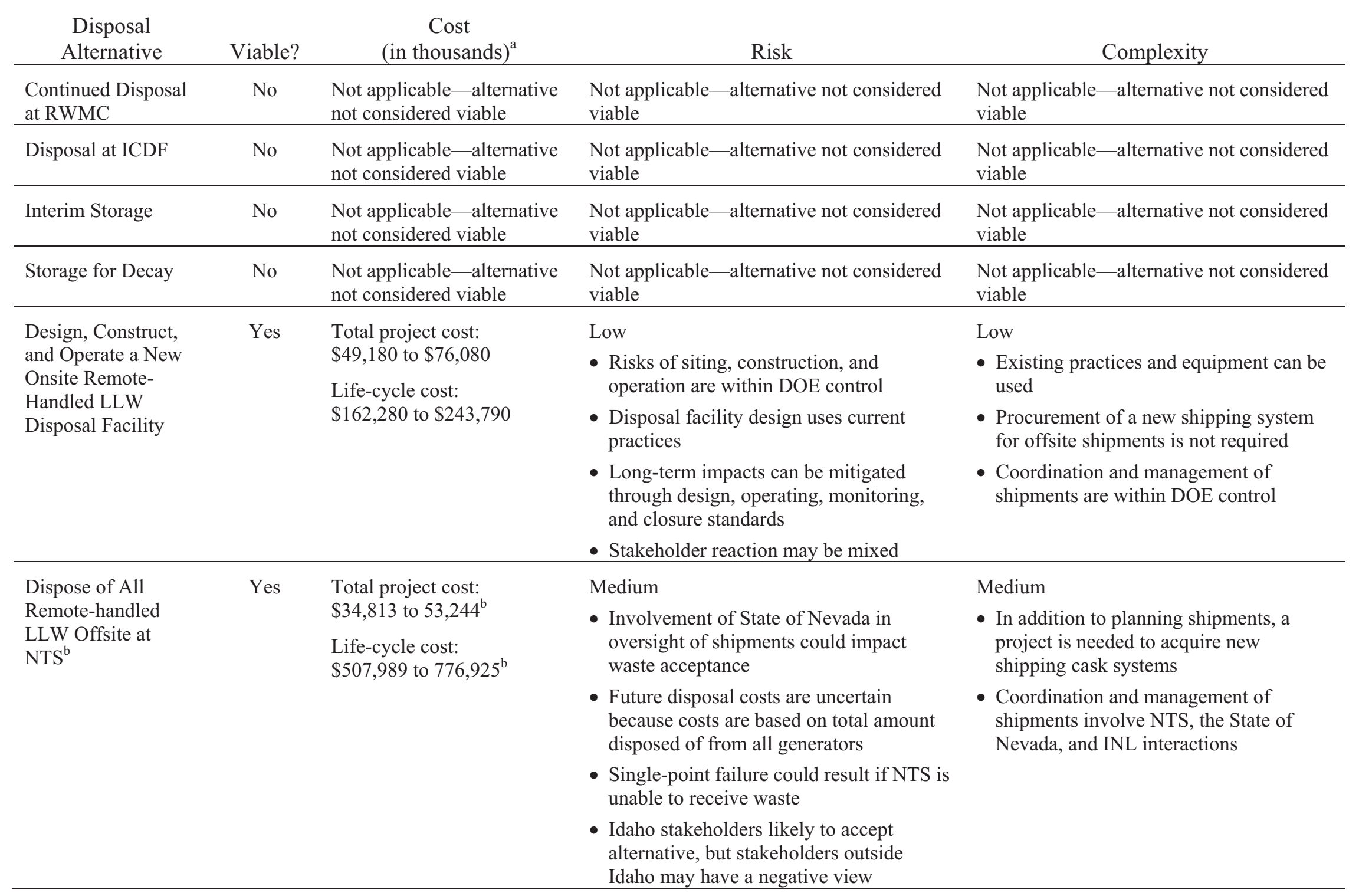




\begin{tabular}{|c|c|c|c|c|}
\hline $\begin{array}{c}\text { Disposal } \\
\text { Alternative }\end{array}$ & Viable? & $\begin{array}{l}\text { Cost } \\
\text { (in thousands) }^{\mathrm{a}}\end{array}$ & Risk & Complexity \\
\hline $\begin{array}{l}\text { Privatization of INL } \\
\text { Remote-Handled } \\
\text { LLW Disposal }\end{array}$ & No & $\begin{array}{l}\text { Not applicable-alternative } \\
\text { not considered viable }\end{array}$ & $\begin{array}{l}\text { Not applicable-alternative not considered } \\
\text { viable }\end{array}$ & $\begin{array}{l}\text { Not applicable-alternative not considered } \\
\text { viable }\end{array}$ \\
\hline No Action & No & $\begin{array}{l}\text { Not applicable-alternative } \\
\text { not considered viable }\end{array}$ & $\begin{array}{l}\text { Not applicable - alternative not considered } \\
\text { viable }\end{array}$ & $\begin{array}{l}\text { Not applicable - alternative not considered } \\
\text { viable }\end{array}$ \\
\hline \multicolumn{5}{|c|}{$\begin{array}{l}\text { a. Costs are presented in terms of FY } 2009 \text { dollars. } \\
\text { b. Offsite disposal at NTS was selected to represent the range of offsite disposal options available because it appears that all of the remote-handled waste streams could meet } \\
\text { the NTS WAC and because NTS is currently available. }\end{array}$} \\
\hline
\end{tabular}

Table 1-2. Options considered for low-level waste disposal.

\section{Options}

Offsite disposal at

Barnwell, South Carolina

Waste Control Specialists, Texas

Oak Ridge, Tennessee

NTS, Nevada

Hanford, Washington

EnergySolutions, Utah

U.S. Ecology, Washington

Savannah River Site, South Carolina

Onsite disposal at

New facility 
Uncertainties in schedules, volumes of waste streams, changing missions, and other unforeseeable circumstances required that a number of assumptions be developed in order to conduct a comprehensive analysis. Assumptions that are specific to a particular disposal alternative are included in those sections of the report where that alternative is presented. The following assumptions provide the general framework by which the report was developed:

- Cost estimates used as the basis of this analysis are rough-order-of-magnitude estimates.

- $\quad$ Project costs are presented by year through FY 2035 for purposes of developing estimates and comparisons of alternatives. FY 2035 was selected as an end date to coincide with commitments for cleanup and movement of DOE spent nuclear fuel; this end date could be extended to accommodate continued management of spent nuclear fuel from the Naval Nuclear Propulsion Program and future mission needs.

- Management reserves averaging 30\% are added to activities or equipment costs to account for future uncertainties.

- $\quad$ Except where specifically noted, the disposal facilities discussed in this plan are assumed to be available through 2035 despite uncertainties associated with LLW disposal capacity, political constraints, and licensing.

- $\quad$ Some packages within individual waste streams may not meet the criteria for the disposal paths described in the report once full characterization occurs. However, for the purposes of this report, schedule and cost estimates assume the entire projected waste volumes will be dispositioned.

- $\quad$ Potential impacts on human health and the environment for disposal of INL LLW will be assessed in a National Environmental Policy Act (NEPA) environmental assessment (EA). 


\section{IDAHO NATIONAL LABORATORY REMOTE-HANDLED LOW-LEVEL WASTE STREAMS}

This section presents a description of the INL remote-handled LLW that will be generated and require disposal between the years 2015 and 2035 .

\subsection{Remote-Handled Low-Level Waste Types and Volume Expected through 2035}

This section describes the two major waste streams that comprise remote-handled LLW. The discussion includes generation rates, total volumes, waste packaging, and radiological characteristics.

\subsubsection{Remote-Handled Low-Level Waste Generation Rates}

INL produces two types of remote-handled LLW: resins and activated metals.

Resin and activated metals waste streams are generated by multiple facilities; Table 2-1 describes these waste streams by generator.

Table 2-1. Remote-handled low-level waste debris, resins, and activated metals waste streams.

\begin{tabular}{|c|c|c|}
\hline $\begin{array}{l}\text { Waste } \\
\text { Stream }\end{array}$ & Generator & Description \\
\hline \multirow{2}{*}{ Resins } & $\begin{array}{l}\text { INL } \\
\text { Advanced Test } \\
\text { Reactor (ATR) } \\
\text { Complex }\end{array}$ & $\begin{array}{l}\text { ATR produces ion exchange resins from pool and reactor } \\
\text { operations. Until September } 30,2008 \text {, the waste was disposed of } \\
\text { in the RWMC pit. Since closure of the RWMC pit, the waste is } \\
\text { being disposed of offsite at NTS. }\end{array}$ \\
\hline & $\begin{array}{l}\text { Naval Reactors } \\
\text { Facility (NRF) }\end{array}$ & $\begin{array}{l}\text { NRF produces ion exchange resins from pool operations. } \\
\text { Currently, the waste is disposed of in the RWMC vaults in liners } \\
\text { transported using a } 55 \text {-ton cask. }\end{array}$ \\
\hline \multirow{3}{*}{$\begin{array}{c}\text { Activated } \\
\text { Metals }\end{array}$} & $\begin{array}{c}\text { INL } \\
\text { ATR Complex }\end{array}$ & $\begin{array}{l}\text { ATR produces activated metals during reactor core change-out } \\
\text { operations approximately every } 8 \text { years. These components } \\
\text { require an approximate } 8 \text {-year decay time and are in storage at } \\
\text { the ATR Complex. Previous disposal has been at RWMC using a } \\
\text { cask that is no longer in use. }\end{array}$ \\
\hline & NRF & $\begin{array}{l}\text { NRF produces activated metals during routine operations. } \\
\text { Currently, waste is disposed of in the RWMC vaults in } 55 \text {-ton } \\
\text { scrap cask liners. }\end{array}$ \\
\hline & $\begin{array}{l}\text { INL } \\
\text { Materials and Fuels } \\
\text { Complex (MFC) }\end{array}$ & $\begin{array}{l}\text { MFC will generate activated metals during waste segregation } \\
\text { operations for waste removed from the storage at the Radioactive } \\
\text { Scrap Waste Facility. No specific cask has been identified. }\end{array}$ \\
\hline
\end{tabular}

The volumes and activity of remote-handled LLW anticipated to be generated through the year 2035 have been forecast. Table 2-2 provides rates of waste generation by location. 
Table 2-2. Waste anticipated to be generated for each remote-handled low-level waste at the Idaho National Laboratory Site.

\begin{tabular}{|c|c|c|c|c|c|c|}
\hline $\begin{array}{c}\text { Waste } \\
\text { Streams }\end{array}$ & Location & Generation & Period & $\begin{array}{c}\text { Current } \\
\text { Transport }\end{array}$ & $\begin{array}{c}\text { Average } \\
\text { Annual } \\
\text { Waste Package } \\
\text { Volume } \\
\left(\mathrm{m}^{3} / \mathrm{yr}\right) \\
\end{array}$ & $\begin{array}{c}\text { MAX Radiation } \\
\text { Levels } \\
\text { Container } \\
\text { Contact } \\
(\mathrm{R} / \mathrm{hr}) \\
\end{array}$ \\
\hline \multirow[t]{2}{*}{ Resins } & ATR Complex & Continuous & $\begin{array}{l}\text { Yearly } \\
(2035)\end{array}$ & $\begin{array}{c}\text { NuPac } \\
\text { 14-210L } \\
\text { (shielding } \\
\text { only) }\end{array}$ & 36 & 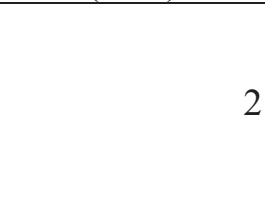 \\
\hline & NRF & Continuous & $\begin{array}{l}\text { Yearly } \\
(2035)\end{array}$ & $\begin{array}{c}\text { 55-ton cask } \\
\text { (shielding } \\
\text { only) }\end{array}$ & 8 & 2 \\
\hline \multirow{3}{*}{$\begin{array}{l}\text { Activated } \\
\text { Metals }^{\mathrm{a}}\end{array}$} & ATR Complex & $\begin{array}{c}\text { Batch } \\
\text { (core } \\
\text { internal } \\
\text { change out) }\end{array}$ & $\begin{array}{c}\sim \text { Every } 8 \\
\text { years } \\
(2035)\end{array}$ & $\begin{array}{c}\text { None } \\
\text { identified }^{\mathrm{b}}\end{array}$ & 3 & 30,000 \\
\hline & $\mathrm{NRF}$ & Continuous & $\begin{array}{l}\text { Yearly } \\
(2035)\end{array}$ & 55-ton cask & 35 & 26,900 \\
\hline & $\begin{array}{l}\text { MFC and other } \\
\text { INL programs }\end{array}$ & Continuous & $\begin{array}{c}\text { Yearly } \\
(2015 \\
\text { through } \\
2024)\end{array}$ & $\begin{array}{c}\text { None } \\
\text { identified }^{\text {b }}\end{array}$ & 6 & 30,000 \\
\hline
\end{tabular}

a. Future projections are that on-contact dose rates will be less than $15,000 \mathrm{R} / \mathrm{hr}$.

b. The CNS 3-60B cask has been identified as a potential candidate (see Appendix B).

\subsubsection{General Characteristics of Remote-Handled Low-Level Waste Packaging}

Remote-handled LLW ion-exchange resins are generated from pool and reactor operations at ATR and from pool operations at NRF. Resins from ATR are packaged in liners and transferred in a Nuclear Packaging (NuPac) 14-210L container for disposal. The INL's NuPac 14-210L cask currently is used for transport of ATR ion-exchange resins to NTS for disposal. This cask is certified as a U.S. Department of Transportation Specification 7A package for low specific activity resins. The cask fully satisfies U.S. Department of Transportation requirements as a Type A package. ATR ion-exchange resin is generated about four to six times per year from reactor loop and reactor ion-exchange systems. The generation rate depends on reactor operations and also varies during the years when core internal change outs are performed. ATR operations generally attempt to fill the cask volume with resins from both resin sources to efficiently use the cask volume.

NRF resins have similar characteristics to and are disposed of onsite in the same manner as NRF activated metals and are included in the same material profile. NRF resins currently are packaged in liners and transported in 55-ton scrap casks to the SDA facility for disposal in vaults. 
Remote-handled LLW activated metals from NRF are currently packaged into the same 55-ton cask liners and shipped in the same 55-ton scrap cask that is used for transporting NRF resins onsite. The 55-ton scrap cask cannot be used for transport on public highways. The NuPac 14-210L cask used for ATR resins does not provide the shielding needed for the activated metal waste. For shipment offsite, U.S. Department of Transportation Type B cask systems will be required. 


\section{OFFSITE ALTERNATIVE FOR REMOTE-HANDLED LOW-LEVEL WASTE DISPOSAL}

This section evaluates the alternative of offsite disposal for INL remote-handled LLW resins and activated metals. Candidate facilities are identified, and the costs, risk, and complexity of offsite disposal are considered.

\subsection{Selection of Offsite Facilities for Evaluation}

Candidate facilities for offsite disposal were identified through literature searches and contacts with disposal facility representatives. Each candidate facility is described and subjected to screening criteria. As a result of this process, one facility was selected for further review based on viability, and was assessed relative to cost, schedule, and risk.

\subsubsection{Candidate Facility Descriptions}

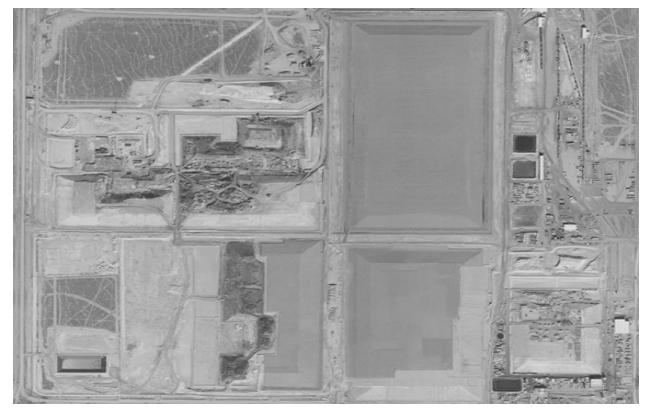

EnergySolutions is located in Tooele County, Utah. It can accept only Class A type LLW as classified under NRC standards. The State of Utah administers the NRC program for facility licensing. The existing license was renewed on September 8, 2009, and expires January 25, 2013.

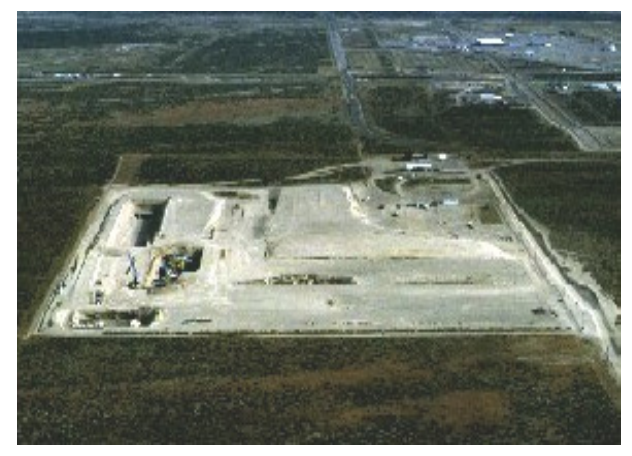

U.S. Ecology is located on 100 acres of land at the DOE Hanford site that are leased by the State of Washington from DOE. The facility can accept Class A, B, and C waste. The State of Washington administers the NRC program for facility licensing. The existing license is valid through 2011 . To date, the facility has received about $13,500,000 \mathrm{ft}^{3}$ of LLW and it has a remaining capacity of $44,000,000 \mathrm{ft}^{3}$. This disposal facility is for Northwest and Rocky Mountain Compact states. Disposal of LLW that is the responsibility of the federal government is subject to state approval.

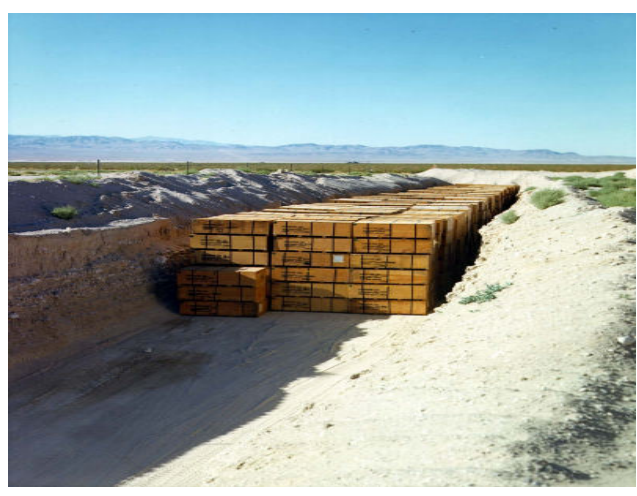

NTS occupies about 1,375 square miles in southeastern Nye County, Nevada. The site is operated by DOE and regulated under DOE Order 435.1 for radioactive waste management. The facility is scheduled to operate through the year 2027 . Waste is disposed of in trenches. 

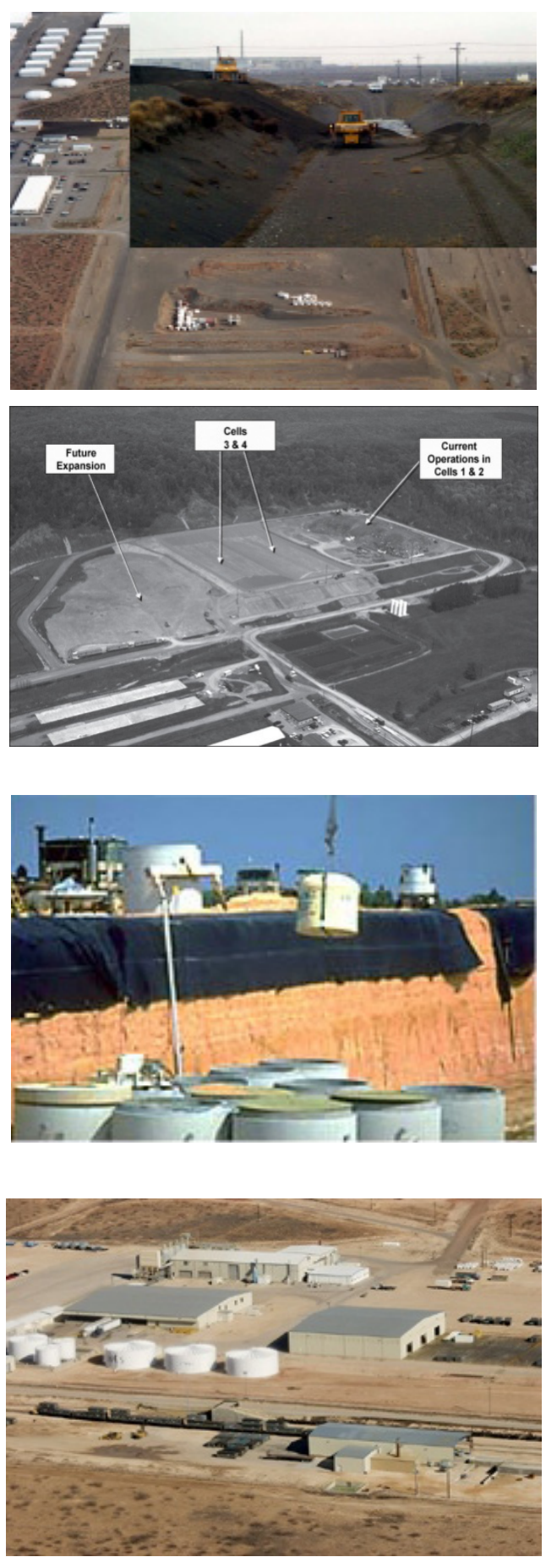

The Hanford Low-Level Waste Burial Grounds on the Hanford site in Washington are operated by DOE and regulated under DOE Order 435.1 for radioactive waste management. Waste is disposed of in trenches. Six Lowlevel waste burial grounds are located in the 200 West Area and two in the 200 East Area of the site. Receipt of offsite waste for disposal at the low-level waste burial grounds is subject to further analysis in an environmental impact statement (EIS). The current schedule for completion of this EIS is under development (DOE 2009b).

\section{The Environmental Management Waste Management} Facility is located on the DOE Oak Ridge Reservation in Tennessee. EMWMF is limited to the receipt of waste from cleanup activities at Oak Ridge and has been in operation since 2002. Management oversight of the EMWMF is the responsibility of DOE, the state, and the Environmental Protection Agency under the requirements of CERCLA (42 USC § 9601) and the Resource Conservation and Recovery Act (42 USC $\S 6901$ ). EMWMF is designed to accept LLW and waste containing hazardous constituents.

The Barnwell Facility, located in Barnwell County, South Carolina, is operated by EnergySolutions, under a lease and license issued by the State of South Carolina. The facility is licensed to accept Class A, B, and C waste for disposal. However, since June 30, 2008, Barnwell is allowed to accept waste from generating facilities within the States of South Carolina, Connecticut, and New Jersey (i.e., the members of the Atlantic Compact) only.

Waste Control Specialists is a facility located in Andrew County, Texas, that will support disposal of federal LLW and Texas Compact waste in separate landfill cells. The State of Texas (the NRC authorized licensing authority) issued Waste Control Specialists a license for disposal of Class A, B, and C LLW on September 10, 2009, conditioned on completion of several administrative requirements. The facility is expected to be opened to LLW disposal in late 2010. Texas has a state law that requires DOE to take possession of the site after closure, if a "federal waste" site is opened. DOE has not made a policy decision to accept future liability for the site after closure. 


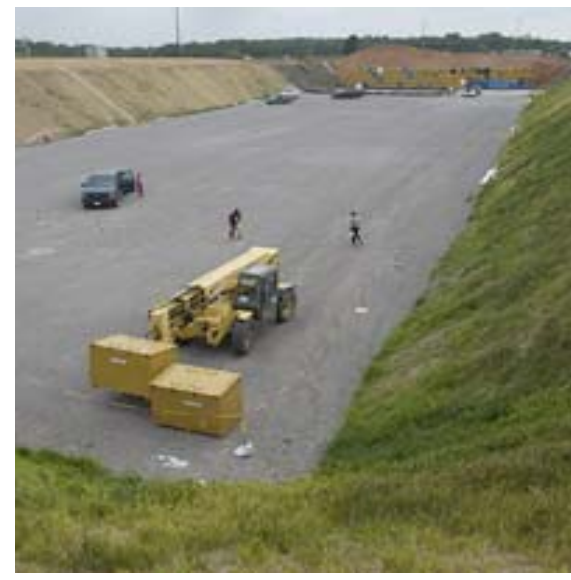

\subsubsection{Candidate Facility Screening}

Several disposal facilities have the capacity to accept all or part of INL's remote-handled LLW. Although waste can be sent to multiple facilities, additional consideration is given to facilities that can accept a majority of waste because only one or minimal additional certification needs be maintained. This reduces cost, quality issues, and overall project risk. One facility, NTS, was selected for purposes of developing costs. This section summarizes the rationale for selection of NTS. While NTS was selected as the offsite option for cost evaluation, other disposal facilities remain an option. The availability and capacity of the other facilities will continue to be evaluated and pursued on an ongoing basis upon commencement of offsite disposal. For a comprehensive screening analysis of facilities for remote-handled LLW disposal, see Low-Level Waste Disposal Alternatives Analysis Report (INL 2006).

The following four offsite facilities were readily eliminated from further consideration because they cannot receive any of the INL remote-handled LLW at this time:

- $\quad$ The EnergySolutions Clive, Utah, facility cannot accept INL remote-handled LLW. The INL's remote-handled LLW resins exceed the EnergySolutions WAC relative to ${ }^{137} \mathrm{Cs}$, ${ }^{90} \mathrm{Sr}$, and ${ }^{99} \mathrm{Tc}$ for this facility. INL remote-handled LLW activated metals, including waste that would be classified as B or C under NRC standards, will not meet the EnergySolutions WAC (INL 2006).

- $\quad$ Barnwell, South Carolina, ceased accepting LLW from states outside the Southeast Compact in 2008.

- $\quad$ EMWMF, Oak Ridge, Tennessee, is not authorized to accept waste from generators off the facility site.

- $\quad$ The DOE Low-Level Waste Burial Grounds at Hanford, Washington, will not be authorized to accept DOE waste from offsite generators until further NEPA documentation is completed. The schedule for completion of the NEPA documentation is under development, and the outcomes of the decisions to be made are unknown (DOE 2009b). Therefore, availability of this facility is too uncertain at this time to consider it as a disposal option.

The remaining facilities selected for analysis as an offsite disposal option for the remote-handled LLW waste streams were further evaluated based on assessments of their WAC and their availability for disposal of INL remote-handled LLW in the timeframe needed. Table 3-1 summarizes the results of this assessment for the remaining four candidate offsite facilities by waste type. 
Table 3-1. Disposal facility screening: waste acceptance criteria compliance and availability relative to low-level waste types ${ }^{\mathrm{a}}$.

\begin{tabular}{|c|c|c|c|c|c|c|c|c|}
\hline \multirow[b]{2}{*}{$\begin{array}{l}\text { Waste } \\
\text { Type }\end{array}$} & \multicolumn{2}{|c|}{ U.S. Ecology } & \multicolumn{2}{|c|}{ Waste Control Specialists } & \multicolumn{2}{|c|}{ NTS } & \multicolumn{2}{|c|}{ Savannah River Site } \\
\hline & $\begin{array}{c}\text { Viable } \\
\text { (Yes/No) }\end{array}$ & Rationale & $\begin{array}{c}\text { Viable } \\
\text { (Yes/No) }\end{array}$ & Rationale & $\begin{array}{c}\text { Viable } \\
\text { (Yes/No) }\end{array}$ & Rationale & $\begin{array}{c}\text { Viable } \\
\text { (Yes/No) }\end{array}$ & Rationale \\
\hline $\begin{array}{l}\text { Remote- } \\
\text { handled } \\
\text { LLW } \\
\text { resins }\end{array}$ & Yes & $\begin{array}{l}\text { State } \\
\text { regulator } \\
\text { buy-in } \\
\text { required to } \\
\text { receive DOE } \\
\text { waste }\end{array}$ & Yes & $\begin{array}{l}\text { Waste meets } \\
\text { WAC } \\
\text { DOE } \\
\text { decision on } \\
\text { use of site is } \\
\text { needed }\end{array}$ & Yes & $\begin{array}{l}\text { Waste meets } \\
\text { WAC } \\
\text { Considered } \\
\text { routine } \\
\text { waste } \\
\text { disposal }\end{array}$ & No & $\begin{array}{l}\text { Cannot } \\
\text { receive } \\
\text { offsite } \\
\text { remote- } \\
\text { handled } \\
\text { LLW resins }\end{array}$ \\
\hline $\begin{array}{l}\text { Remote- } \\
\text { handled } \\
\text { LLW } \\
\text { activated } \\
\text { metals }\end{array}$ & Partial & $\begin{array}{l}\text { State } \\
\text { regulator } \\
\text { buy-in } \\
\text { required to } \\
\text { receive DOE } \\
\text { waste } \\
\text { A portion of } \\
\text { the waste } \\
\text { exceeds } \\
\text { Class C }\end{array}$ & Partial & $\begin{array}{l}\text { A portion of } \\
\text { the waste } \\
\text { exceeds } \\
\text { Class C } \\
\text { DOE } \\
\text { decision on } \\
\text { use of site is } \\
\text { needed }\end{array}$ & Yes & $\begin{array}{l}\text { Waste } \\
\text { conditionally } \\
\text { meets WAC } \\
\text { (special } \\
\text { Performance } \\
\text { Assessment } \\
\text { requirement) }\end{array}$ & Partial & $\begin{array}{l}\text { Only NRF } \\
\text { activated } \\
\text { metal } \\
\text { components } \\
\text { can be } \\
\text { accepted }\end{array}$ \\
\hline
\end{tabular}

a. Appendix B of the Low-Level Waste Disposal Alternatives Analysis Report (INL 2006) details the screening analysis. 
The following paragraphs provide detailed rationale associated with the screening criteria results for the candidate facilities.

U.S. Ecology. The INL Site's resin waste stream is expected to meet the U.S. Ecology disposal acceptance requirements. The remote-handled activated metal waste that is Class B and C is expected to meet the disposal acceptance requirements; however, there exists a portion of the waste that exceeds 10 Code of Federal Regulations (CFR) Part 61 definition of Class $\mathrm{C}$ and could not be accepted. The activated metal waste characteristically has significant quantities of ${ }^{14} \mathrm{C},{ }^{63} \mathrm{Ni},{ }^{59} \mathrm{Ni},{ }^{60} \mathrm{Co}$, and ${ }^{3} \mathrm{H}$ over a 20 -year disposal schedule, which in some cases could have significant impact on the disposal facility's license radiological limits (INL 2006).

U.S. Ecology has not received DOE waste to date, and they would need to open dialogue with the State of Washington to reach agreement on the acceptance of the waste. Given the repeated efforts by the State of Washington to prevent offsite waste from going to Hanford, any proposal to receive DOE waste at U.S. Ecology could be met with resistance from the state.

Savannah River Site. Savannah River Site can accept only NRF remote-handled LLW activated metal for disposal by truck or rail. However, it cannot accept remote-handled LLW activated metal from ATR or MFC, or remote-handled LLW resins. Therefore, it is screened from consideration as a primary option. It may be reviewed in the future for NRF's activated metals if the other options are not available.

Waste Control Specialists. Waste Control Specialists has been issued a license to accept Class A, $\mathrm{B}$, and C LLW for disposal at its site in Texas, conditioned on completion of several administrative requirements. The facility is expected to be opened to LLW disposal in late 2010. DOE policy has to be resolved regarding acceptance of the facility after closure. However, the facility does appear to provide a viable option for disposal of much of the INL remote-handled LLW.

As with the U.S. Ecology facility, the remote-handled activated metal waste that is Class B and C is expected to meet the disposal acceptance requirements at the Waste Control Specialists facility; however, a portion of the waste exists that exceeds 10 CFR 61 Class $\mathrm{C}$ that could not be accepted. The activated metal waste characteristically has significant quantities of $14 \mathrm{C}, 63 \mathrm{Ni}, 59 \mathrm{Ni}, 60 \mathrm{Co}$, and $3 \mathrm{H}$ over a 20-year disposal schedule, which in some cases could have significant impact on the disposal facility's license radiological limits.

NTS. The INL remote-handled LLW meets the elements of the NTS WAC or is a viable candidate for a special performance assessment for waste that may exceed the NTS WAC radionuclide action levels. NTS has extensive experience disposing of remote-handled waste. NRF remote-handled LLW resins and activated metals can be accepted by NTS with some infrastructure changes at NRF to accommodate waste packaging.

The State of Nevada participates in review of waste material profiles and has access to LLW disposal waste information through an Agreement in Principle with DOE (DOE-NV 1999). NTS identified no issues that would cause the state to view the activated metals as unacceptable for disposal, although the facility has not received routine shipments of high-radiation waste of this nature in the past. Impacts to the facility's infrastructure are anticipated; however, they have not been fully assessed. In addition, the political climate could change by the year 2016 and be less favorable. LLW disposal cells at NTS are currently scheduled to close in the year 2027. This poses a risk that if NTS is selected, it will only be available for 14 years, and that large financial investments in disposing of waste at NTS will yield limited returns. 


\subsubsection{Screening Results}

Because it appears that all INL's waste can be disposed of at NTS and it is currently available, it was selected for further analysis. Because NTS is suitable for all LLW, INL would only need to maintain one certification program for waste shipments, minimizing costs of program administration and oversight. Analysis of costs, risks, and complexity of using NTS will be considered representative of scenarios in which the commercial options of U.S. Ecology or Waste Control Specialists might be included for the remote-handled resins or a portion of the activated metal waste.

\subsection{Analysis of Offsite Disposal of Remote-Handled Low-Level Waste}

This section evaluates the potential for offsite disposal of all INL remote-handled LLW at NTS, including resins generated by ATR and NRF and activated metals generated by ATR, NRF, MFC, and potentially other INL activities. ATR resins are already being disposed of at NTS. To be viable as a disposal path for the remainder of the INL remote-handled LLW, the necessary documentation, procedures, and infrastructure must be in place prior to October 2015 when the SDA vaults are no longer available. Activated metals pose the greatest challenge to offsite disposal due to the amount of shielding required for transportation and transfer operations. While NTS is selected as the base case for analysis, differences between NTS and the potentially viable commercial options of U.S. Ecology and Waste Control Specialists are identified where applicable.

\subsubsection{Assumptions and Strategies}

Assumptions and strategies used to develop this alternative include the following:

- Based on the current CERCLA closure schedule, it is assumed that the SDA will remain open for disposal of remote-handled LLW in the vaults for sufficiently long that onsite storage capacity will not be exceeded prior to procurement of required casks and completion of necessary infrastructure changes.

- $\quad$ Disposal of INL remote-handled LLW will be required at least through the year 2035.

- $\quad$ Waste profiles will be developed by INL waste generators and approved by NTS.

- A dose rate of $15,000 \mathrm{R} / \mathrm{hr}$ for the remote-handled LLW activated metals is selected for purposes of analysis. Projections indicate that future radiation levels are expected to be below this level. Any waste that is over $15,000 \mathrm{R} / \mathrm{hr}$ could be stored to allow decay to this level.

\subsubsection{Shipping Considerations and Assumptions} following:

With NTS selected as the viable alternative, shipping and packaging considerations include the

- ATR is estimated to require six shipments per year for its resin waste with $6 \mathrm{~m}^{3}$ in each shipment. The ATR remote-handled LLW ion-exchange resins are currently shipped offsite in a NuPac 14-210L shipping container for shielding. It is assumed this procedure will continue for offsite shipments of remote-handled LLW resins from ATR. 
- $\quad$ Commercial truck-loaded casks will be required to meet the configuration and shielding requirements for offsite shipment of remote-handled LLW ion-exchange resins and activated metals from NRF and activated metals from ATR and MFC (see Appendix B). To send these remote-handled LLW streams to NTS, six casks will be needed to make 50 shipments per year (43 from NRF, four from MFC, and three from ATR) at an anticipated waste generation of $50 \mathrm{~m}^{3}$. A trailer is needed for each cask. Four shielded transfer systems also will be required to accommodate disposal shipping activities. Five casks would be used by NRF and one will be shared between ATR and MFC.

- Infrastructure considerations for shipping offsite to NTS include the following:

-Modifications to NRF infrastructure will be required to accomplish offsite disposal. NRF will need to design a loading station for a commercial cask or repackage to a different disposal liner/system.

-Associated shipping procedures will need to be developed at NRF to accommodate the new cask size and liner handling.

- Activated metals from MFC would be segregated and repackaged at the Idaho Nuclear Technology Engineering Center into a form suitable for transfer to a cask for shipping.

-NTS will need to adopt specific procedures, perform special performance assessments, and rent extra equipment in order to receive and dispose of this waste.

\section{2 .3}

\section{Schedule}

The schedule for disposal offsite for remote-handled LLW resins and activated metals, presented in Figure 3-1, includes infrastructure development at NRF and cask procurement. This schedule does not include cask design as an available cask design (i.e., the CNS 3-60B cask) has been identified.

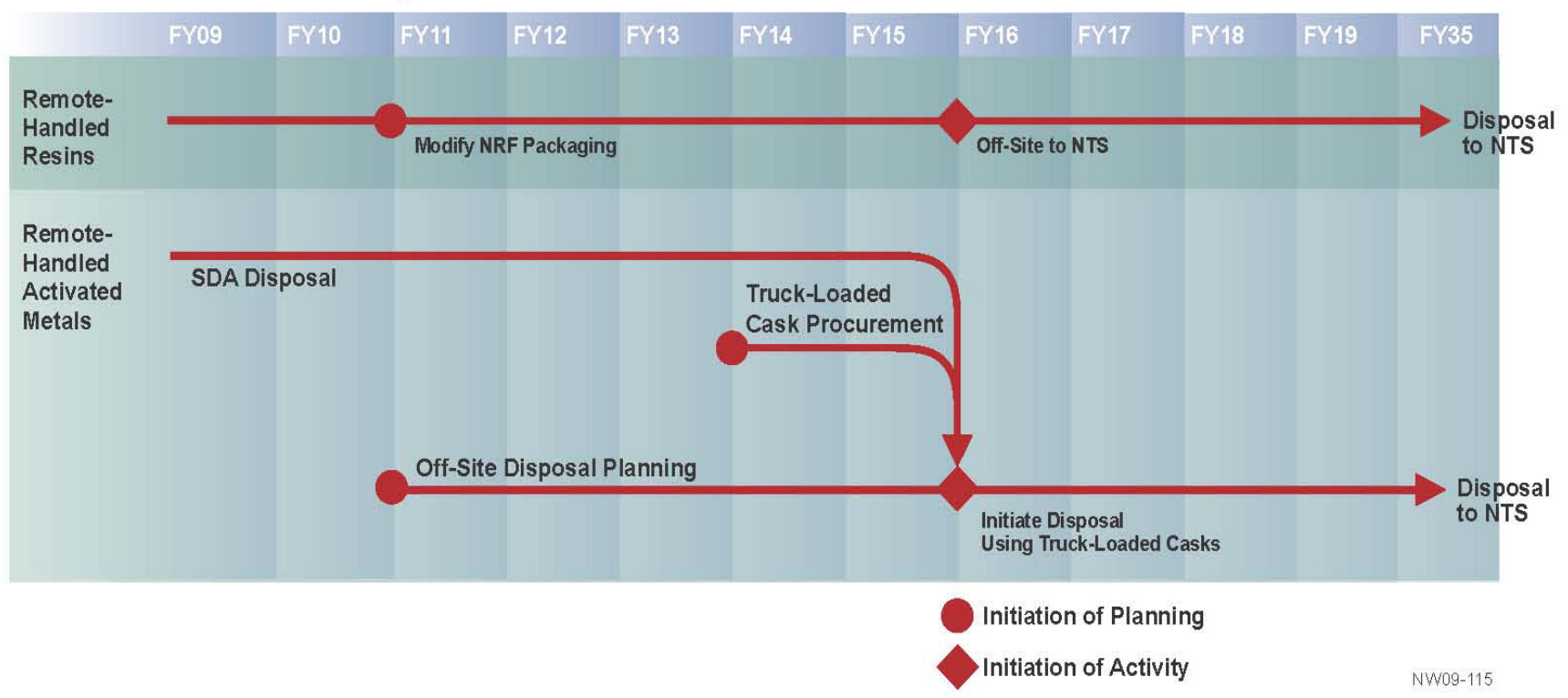

Figure 3-1. Schedule for offsite disposal activities for remote-handled low-level waste resins and activated metals using truck-loaded casks. 


\subsubsection{Cost}

The costs for preparation and offsite disposal of remote-handled LLW activated metals and resins at NTS from FY 2016 through FY 2035 include escalation throughout the performance period in accordance with DOE escalation rates, and appropriate management reserves are associated with each activity.

There are anticipated impacts to the facility's infrastructure associated with changes to operating procedures for the NRF resins; however, they have not been fully assessed and are not included.

Costs for disposal at NTS are based on current charges. However, future disposal costs are uncertain as costs charged to the generator in a given year are based on the total amount of waste disposed of at the facility. NTS maintenance and training costs are included, but costs of infrastructure changes have not been fully assessed and are not included. Additionally, costs may increase if the disposal site (NTS) needs to recover costs for required infrastructure changes.

The costs for disposal of remote-handled LLW resins from ATR are based on renting shipping containers for 7 to 10 day rental periods per year. Further cost evaluation is needed to determine whether it is more cost-effective to purchase shipping containers. It is assumed that the type of resin liners currently used by ATR will continue to be used.

Costs for shipment of activated metals and NRF ion-exchange resins to NTS include acquisition of casks and purchase of 50 cask liners per year for 20 years. Transportation and disposal costs include development of material profiles and waste characterization.

Total costs through 2035 are $\$ 598$ million. Costs for transportation and disposal of the activated metals and NRF ion-exchange resins account for $\$ 535$ million of this total and are attributable to the limited volume of waste that can be included in a shipment and the resulting number of shipments required. Appendix $\mathrm{C}$ provides additional cost and schedule details for this alternative.

\subsubsection{Risk}

Shipping waste has inherent risks associated with commercial shipment of goods.

NTS is regulated by DOE and disposal is not anticipated to be a problem from a technical standpoint. NTS has received remote-handled LLW in the past, although it has not received shipments of high-radiation waste of this nature and impacts to infrastructure have not been fully addressed. The State of Nevada participates in review of waste material profiles and has access to LLW disposal waste information through an Agreement in Principle with DOE (DOE-NV 1999). No issues have been identified that would cause the state to view the remote-handled LLW as unacceptable for disposal. However, the political climate could change in the future and be less favorable to accepting these waste streams.

LLW disposal at NTS is an Office of Environmental Management program on a National Nuclear Security Administration (NNSA) site. The Office of Environmental Management is planning to transfer ownership of the LLW disposal cells at NTS in 2027 to NNSA. The facility has disposal capacity beyond 2027, but disposal of LLW after 2027 will have to be agreed to by NNSA. This poses a risk that the facility will not be available beyond 2027. The commercial options of U.S. Ecology and Waste Control Specialists also present the risk that licenses for operation will not be renewed by the state regulator, introducing some risk. 
Future disposal costs are uncertain as costs charged to the generator in a given year are based on the total amount of waste disposed of at the facility. There is a risk that disposal costs will increase as the volume of waste shipped to NTS over time decreases. The INL costs could increase significantly to support NTS base facility disposal operations costs. There is the possibility that toward the end of NTS' operating life, INL will have to support the full burden of the facility. With commercial facilities such as U.S. Ecology and Waste Control Specialists, future costs also are uncertain since costs are set by the receiving facilities based on market conditions.

Shipping remote-handled LLW activated metals and resins to NTS results in a single point failure if NTS is unable to receive the waste due to stakeholder or regulator concerns. While the State of Idaho and stakeholders may view this alternative in a positive light in that waste will be leaving the state, stakeholders outside Idaho may have a negative view.

\subsubsection{Complexity}

Accomplishment of this alternative involves coordination of schedules, interfaces, and project execution between INL and another facility. In addition to the direct work required to implement the alternative, an additional project must be carried out to acquire new shipping cask systems. Juggling the interrelated cost and schedule demands of two projects introduces a measure of complexity and risk into this alternative. 


\section{ONSITE DISPOSAL ALTERNATIVE}

This section evaluates the remote-handled LLW disposal alternative of disposal in a new onsite facility.

\subsection{Siting and Design Considerations for Onsite Disposal of Idaho National Laboratory Remote-Handled Low-Level Waste}

For this alternative, it was assumed that the remote-handled LLW inventory will be retained and disposed of onsite beginning in FY 2016, upon closure of the SDA LLW disposal facility. No technical barriers have been identified that will prevent implementation of an onsite alternative.

\subsubsection{Siting}

Selection of a candidate location for onsite disposal at the INL site is subject to the requirements of DOE Order 435.1 and implementing guidance for LLW facilities. A siting evaluation must consider the environmental characteristics, geotechnical characteristics, and human activities. A LLW disposal facility location study must specifically address: suitability for volume of waste, flood plain, tectonic activity, water table fluctuation, access, wildlife, whether radionuclide migration pathways are predictable, and whether erosion and surface runoff can be controlled.

Several such studies have been prepared for proposed INL site facilities. Also, substantial data regarding site conditions are available from environmental monitoring, sampling and analysis, and other studies that are routinely performed at INL. A study conducted in 1997 includes an evaluation of 16 candidate locations at the INL site (INEEL 1997). The study was performed for one specific waste stream from separation of calcined and liquid waste with a projected volume of $25,000 \mathrm{~m}^{3}$. It provides an excellent baseline for further evaluation for the waste described in this report. It screened sites according to the following four "must" criteria:

1. Avoid the 100-year floodplain

2. Avoid wetlands

3. Avoid critical habitat of endangered species

4. Avoid areas in which tectonic processes may affect ability of the facility to meet performance objectives or may preclude defensible prediction of long-term impacts.

Sites that passed the screening were assessed for 19 criteria that addressed minimizing impacts to resources, accessibility, suitability for waste volume and expansion, and impeding downward migration of contaminants. The study identified several locations on the INL site suitable for an LLW landfill. The data and criteria in the 1997 study will have to be updated, and the locations reconsidered in light of the different waste volumes and characteristics, but it is likely that a similar conclusion will be reached for the remote-handled LLW that is the subject of this report.

Full consideration of the siting issues for candidate sites is outside the scope of this report. For the purpose of this analysis, we have assumed that a suitable location for a remote-handled LLW disposal facility exists at INL, and that a site will be generally suitable both technically and economically as a disposal facility location. 
Once a site is identified by optimizing all the technical and cost parameters, additional geotechnical investigation is needed to confirm suitability and identify a specific location for the facility. The costs for planning, conducting field work, and reporting on results comprise the costs for siting included in the cost estimate given further below in this section of the report. The data generated will be used to complete the facility design.

\subsubsection{Disposal Facility Description/Waste Acceptance Criteria}

This section further considers the alternative to build and maintain a disposal facility on the INL site specifically designed to safely dispose of remote-handled LLW through the year 2035.

For this preliminary analysis of an onsite remote-handled LLW disposal cell, the projected annual average generation rate of remote-handled LLW resins and activated metals is estimated to be approximately $88 \mathrm{~m}^{3}$ through the year 2035. Of the expected $88 \mathrm{~m}^{3}$ of remote-handled LLW, $36 \mathrm{~m}^{3}$ are ATR resins that had previously been disposed of in pits at RWMC. This waste currently is shipped offsite to NTS due to closure of the pits. If a new disposal facility is constructed, it is assumed that it would be more cost effective to resume disposal of these resins onsite and to retain disposal at NTS as a contingent option. The other remote-handled LLW activated metal waste types currently disposed of at RWMC are disposed of in the concrete vaults (see Figure 4-1).

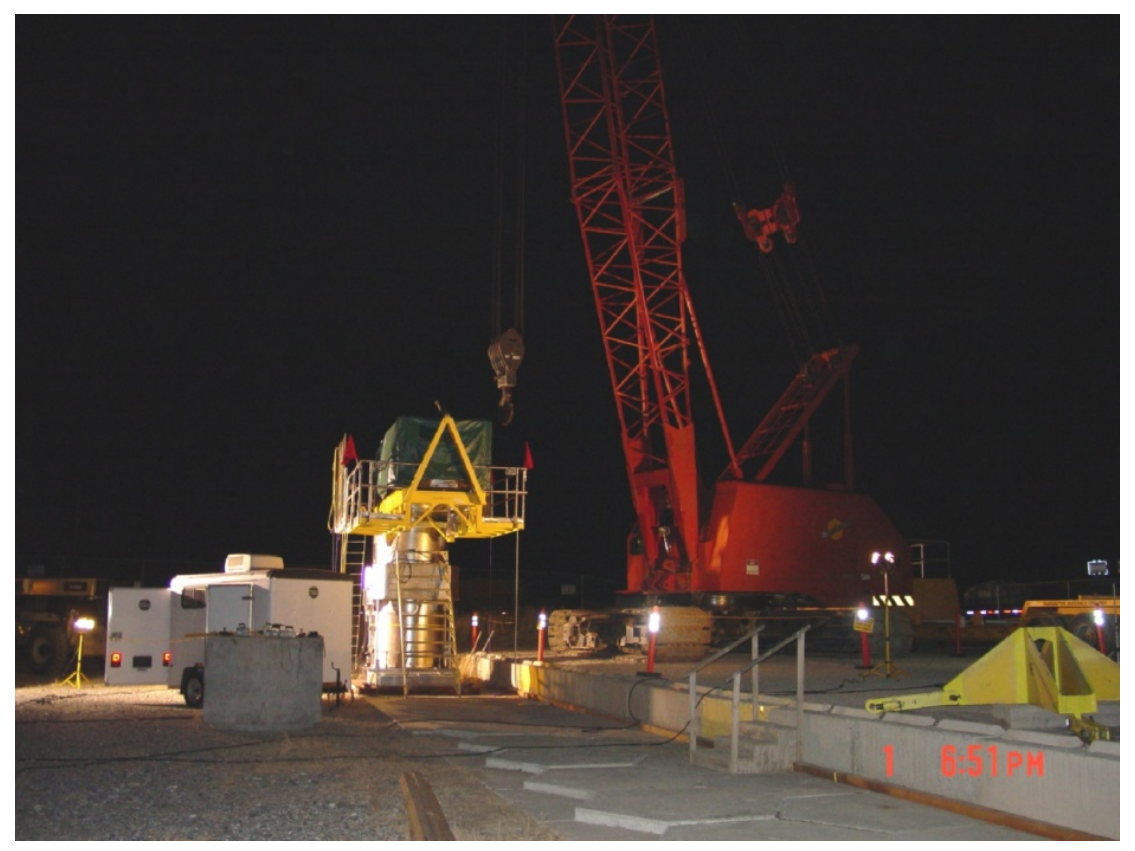

Figure 4-1. Remote-handled concrete vaults.

The new onsite facility design will dispose of all remote-handled LLW waste in concrete vaults. The number of remote-handled concrete vaults required is based on the configuration of vaults and the transportation containers used by the generating facilities rather than the volumetric fill efficiency. Three configurations of concrete vaults would be required for the new onsite facility.

The first design is based on the RWMC vaults, which are suitable for the 55-ton cask liner used by NRF for transport of remote-handled LLW. These vaults are made from pre-cast concrete. They have a circular cross section and are approximately $1.5 \mathrm{~m}$ in diameter and $6 \mathrm{~m}$ high. These vaults can 
accommodate two stacked 55 -ton cask liners (1.22 $\mathrm{m}$ diameter by $2.82 \mathrm{~m}$ high). Each liner holds approximately $3 \mathrm{~m}^{3}$ of waste.

Of the expected $88 \mathrm{~m}^{3}$ of remote-handled LLW, $43 \mathrm{~m}^{3}$, comprising all NRF remote-handled LLW activated metals and NRF resins, will be disposed of in the concrete vaults of this design. At $6 \mathrm{~m}^{3}$ of this type of remote-handled LLW waste per vault, approximately eight vaults will be needed each year. For the assumed 20-year operation period approximately 162 vaults will be needed.

A second vault configuration will be designed for the shipments of remote-handled LLW activated metals from MFC and ATR. The vaults will be made of pre-cast concrete and designed to accommodate two shipments each of waste in a liner that is $3.2 \mathrm{ft}$ in diameter and $9.25 \mathrm{ft}$ in length. A total of 50 shipments over the 20 -year operating life of the disposal facility are planned, and 25 vaults will be required.

The third vault design is based on the configurations of the containers used by ATR for transport of remote-handled LLW resins. These vaults also are made from pre-cast concrete. They are approximately $2.1 \mathrm{~m}$ in diameter and $6 \mathrm{~m}$ high to accommodate the NuPac 14-210L shipping container liners. One vault can hold two liners, each liner holding approximately $6 \mathrm{~m}^{3}$ of waste resin. The number of this type of cask required is determined by the planned shipping schedule from the generator facilities. Approximately six shipments per year are planned, each of which will contain a single liner. To accommodate six shipments per year for 20 years, 60 of this type of vault would be required.

\subsection{Analysis of Onsite Disposal of All Remote-Handled Low-Level Waste}

This section analyzes the alternative of onsite disposal for the INL remote-handled LLW.

\subsubsection{Assumptions and Strategies}

The approach taken was to use existing information from the ICDF project with modifications to cost and schedule to reflect the current projected waste volumes for remote-handled LLW, NEPA regulations (42 USC § 4321) versus CERCLA regulations (42 USC § 9601), safety analysis assumptions for a Hazard Category 2 facility, and remote-handled LLW disposal. The following assumptions and strategies were used to develop the cost and schedule for the new onsite remote-handled LLW disposal facility:

- $\quad$ Costs for remote-handled LLW vaults are based on actual costs for the construction of new disposal vaults at RWMC between 2001 and 2003.

- $\quad$ Although the vault design assumptions do not meet Resource Conservation and Recovery Act Subtitle $\mathrm{C}$ liner requirements for mixed LLW, the design includes engineered features that take into account operational impacts and are protective of groundwater (Appendix A).

- The use of removable concrete covers for the remote-handled LLW vaults will likely simplify the cover design relative to that required over the cells.

- The remote-handled LLW can be handled in a similar manner as it is today at the SDA. A crane and support equipment are used to move the cask over the top of the vault, lower the liner into the vault, and seal the vault. 
- $\quad$ An EA, not an EIS, will be prepared to comply with NEPA. The EA will tier from the analyses and decisions made in the 1995 INL EIS on environmental restoration and waste management (DOE 1995).

- $\quad$ Operational costs associated with the SDA pit and vaults were used for estimating purposes.

- A 30\% management reserve was applied and should cover any additional costs related to reasonable enhancements instituted as best management practices.

- $\quad$ No costs for changes in infrastructure for shipping, packaging, and temporary storage are anticipated to be needed in order to achieve onsite disposal of remote-handled LLW.

The following actions or approvals are needed from DOE per the schedules in Appendix C to implement this alternative:

- $\quad$ CD-1 through CD-4 for an onsite LLW landfill

- $\quad$ EA determination and Finding of No Significant Impact based on the EA for the Remote-Handled LLW Disposal Project

- $\quad$ Operational readiness review.

\subsubsection{Schedule}

Figure 4-2 presents the schedule for construction of an onsite disposal facility. This schedule assumes that this facility will be developed and funded as a capital project.

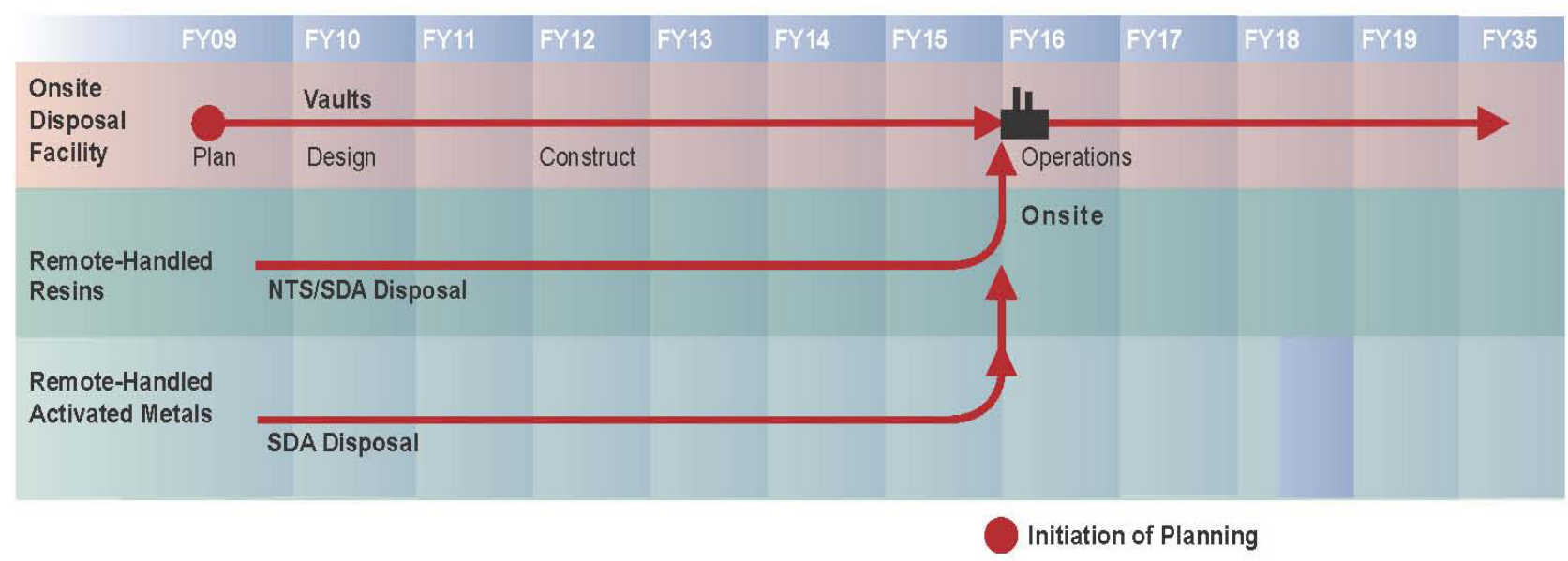

NW09-116

Figure 4-2. Remote-handled low-level waste disposal onsite.

\subsubsection{Costs}

The costs for disposal of remote-handled LLW in an onsite disposal facility include siting, design, and construction of infrastructure; maintenance of disposal authorization; safety documentation; project management; operations; and closure. Costs are escalated and include an appropriate management reserve. Operational costs associated with the SDA vaults were used for estimating purposes. A 
management reserve was applied and should cover any additional costs related to reasonable enhancements instituted as best management practices. Costs for the onsite disposal facility construction and operation through the year 2035 total \$191 million.

\subsubsection{Risk}

Overall risk for this alternative is considered low because the risks involved with siting, construction, and operation are largely under the control of DOE and do not involve out-of-state transport. The facility will be designed using experience, practices, and materials, which introduce little design risk. The potential risk of long-term impacts to the aquifer can be mitigated through use of design, operating, monitoring, and closure standards. Stakeholders will have involvement through the NEPA process and other established public and regulator forums as appropriate. If the alternative of a new facility is selected, stakeholder concerns about location can be addressed via the site selection criteria used in the facility siting assessment. Stakeholders also have expressed concerns that a new INL facility would be made available for disposal of waste from offsite; however, use of INL for offsite waste disposal is not a decision DOE has made pursuant to NEPA. INL is restricted to disposal of LLW from onsite only based on DOE's record of decision for LLW (DOE 2000). Concerns for protection of the aquifer have been paramount, and therefore, stakeholder reactions to disposal of LLW onsite could be mixed. In particular, concern could be expressed regarding the fact that the landfill cells are not equipped with artificial liners. Stakeholder perceptions on the applicability of a liner may induce a strong reaction and could impact cost and schedule.

If planned funding is not available, impact to proposed schedule could require development of interim storage for remote-handled LLW at an onsite facility.

\subsubsection{Complexity}

This alternative involves just one facility. Because all shipments occur within site boundaries, existing transport practices and equipment can be used. This completely eliminates the costs, risks, and schedule impacts of development of a new transportation cask system and simplifies the coordination and management of shipments. 


\section{REMOTE-HANDLED LOW-LEVEL WASTE DISPOSAL ALTERNATIVE EVALUATION}

The alternatives for remote-handled LLW disposal are evaluated and compared in this section. Each alternative encompasses all remote-handled LLW disposal needs for INL. More detailed cost and schedule information for each alternative, including total operating and capital costs by year, is provided in Appendix C.

Each alternative was ranked in accordance with the criteria identified in Table 5-1. Each criterion was assigned a relative weighting factor from 1 to 3 . Each alternative was assigned a score of 1 to 5 based on the ability of the alternative to meet the criteria, with a 5 representing the highest possible score. The alternative with the highest total score represents the preferred alternative for providing continued, uninterrupted remote-handled LLW disposal capability for INL operations.

Based on the ranking presented in Table 5-1, the highest ranked alternative is the development of a new onsite remote-handled LLW disposal facility. Onsite disposal of INL and tenant-generated, remote-handled LLW has the lowest life-cycle cost to DOE and provides the lowest risk. Costs are reduced through avoidance of costs to develop transportation infrastructure and to conduct offsite shipments. Project risks, such as uncertainty of availability of offsite facilities, are eliminated using onsite disposal. Reliance on other activities or programs in order to achieve disposal also is minimized, reducing disposal complexity.

Offsite disposal, in addition to having a higher life-cycle cost due to the limitations on the amount of remote-handled LLW that can be packaged into each container for transport, is complicated by transportation issues associated with transporting highly radioactive waste in commerce and the infrastructure and processing changes at the generating facilities, specifically NRF, that would be required to support offsite disposal.

Table 5-1. Ranking of alternatives for Idaho National Laboratory remote-handled low-level waste disposal capability.

\begin{tabular}{lccccc}
\hline \multicolumn{1}{c}{ Criteria } & \multicolumn{2}{c}{ Alternative Rank } & \multicolumn{2}{c}{ Total Weighted Score } \\
\cline { 2 - 6 } & $\begin{array}{c}\text { Weighting } \\
\text { Factor }\end{array}$ & $\begin{array}{c}\text { Onsite } \\
\text { Disposal }\end{array}$ & $\begin{array}{c}\text { Offsite } \\
\text { Disposal }\end{array}$ & $\begin{array}{c}\text { Onsite } \\
\text { Disposal }\end{array}$ & $\begin{array}{c}\text { Offsite } \\
\text { Disposal }\end{array}$ \\
\hline $\begin{array}{l}\text { Capital project expenditure (total } \\
\text { project cost) }\end{array}$ & 2 & 5 & 1 & 10 & 2 \\
$\begin{array}{l}\text { Life-cycle cost to Office of Nuclear } \\
\begin{array}{l}\text { Energy and Office of Naval Reactors } \\
\text { Potential for "single-point" failure in }\end{array}\end{array}$ & 2 & 5 & 1 & 10 & 2 \\
$\begin{array}{l}\text { disposing of INL remote-handled } \\
\text { LLW }\end{array}$ & 3 & 5 & 1 & 15 & 3 \\
$\begin{array}{l}\text { Interaction of third parties in } \\
\text { regulation of waste transport/disposal } \\
\text { activities }\end{array}$ & 1 & 3 & 2 & 3 & 2 \\
$\begin{array}{l}\text { Potential impacts on Office of } \\
\text { Nuclear Energy and Office of Naval }\end{array}$ & 3 & 5 & 2 & 15 & 6 \\
$\begin{array}{l}\text { Reactors operations } \\
\text { Idaho stakeholder opposition }\end{array}$ & 2 & 2 & 5 & 4 & 10 \\
\hline Total & & & 54 & 25 \\
\hline
\end{tabular}




\section{SUMMARY AND RECOMMENDATIONS}

This report presents the evaluation of the alternatives for disposal of remote-handled LLW generated by activities on the INL Site after closure of the SDA. The objective of this report is to provide a recommendation on the preferred alternatives for future remote-handled LLW disposal, after systematic consideration of cost, schedule, and risks of the viable alternatives for both offsite and onsite disposal.

Based on the ranking analysis, the order of recommendation for the two alternatives is:

- Construct a new remote-handled LLW vault facility and dispose of all remote-handled LLW on the INL Site

- $\quad$ Ship all remote-handled LLW to NTS for disposal.

The onsite disposal alternative was ranked higher than the alternative of offsite disposal in all categories except Idaho stakeholder opposition, having the lowest cost, lowest risk, and being the least complex to implement. Figure 6-1 graphically illustrates the cost advantages of the onsite disposal alternative as total project costs (rounded to the nearest hundred thousand) over the duration of the project. It shows that building a facility on the INL site for disposal of remote-handled LLW has the lowest total project cost. While both alternatives involve initial investments, the onsite alternative has a lower growth rate and a flatter funding profile.

The onsite disposal alternative involves lower risk because it presents no offsite transportation or disposal considerations. In the recommended alternative, the risks are all, at least to some degree, under DOE control. Procurement of casks systems for offsite transportation is eliminated, decreasing cost and schedule risk. Coordination among a series of parallel programs is not required. Dependence on the cooperation of third parties, such as disposal site operators, or states other than Idaho, is reduced to the absolute minimum. The onsite disposal alternative does involve increased Idaho stakeholder concerns as compared to offsite disposal. Stakeholder considerations will be addressed as part of the NEPA process, which will provide opportunity for comment on DOE's proposed action. In addition to a formal public comment period, stakeholder input also will be solicited via a series of public meetings and forums.

Successful implementation of the recommended alternative depends on the availability of planned funding. Significant delay in funding could require establishment of onsite storage. 


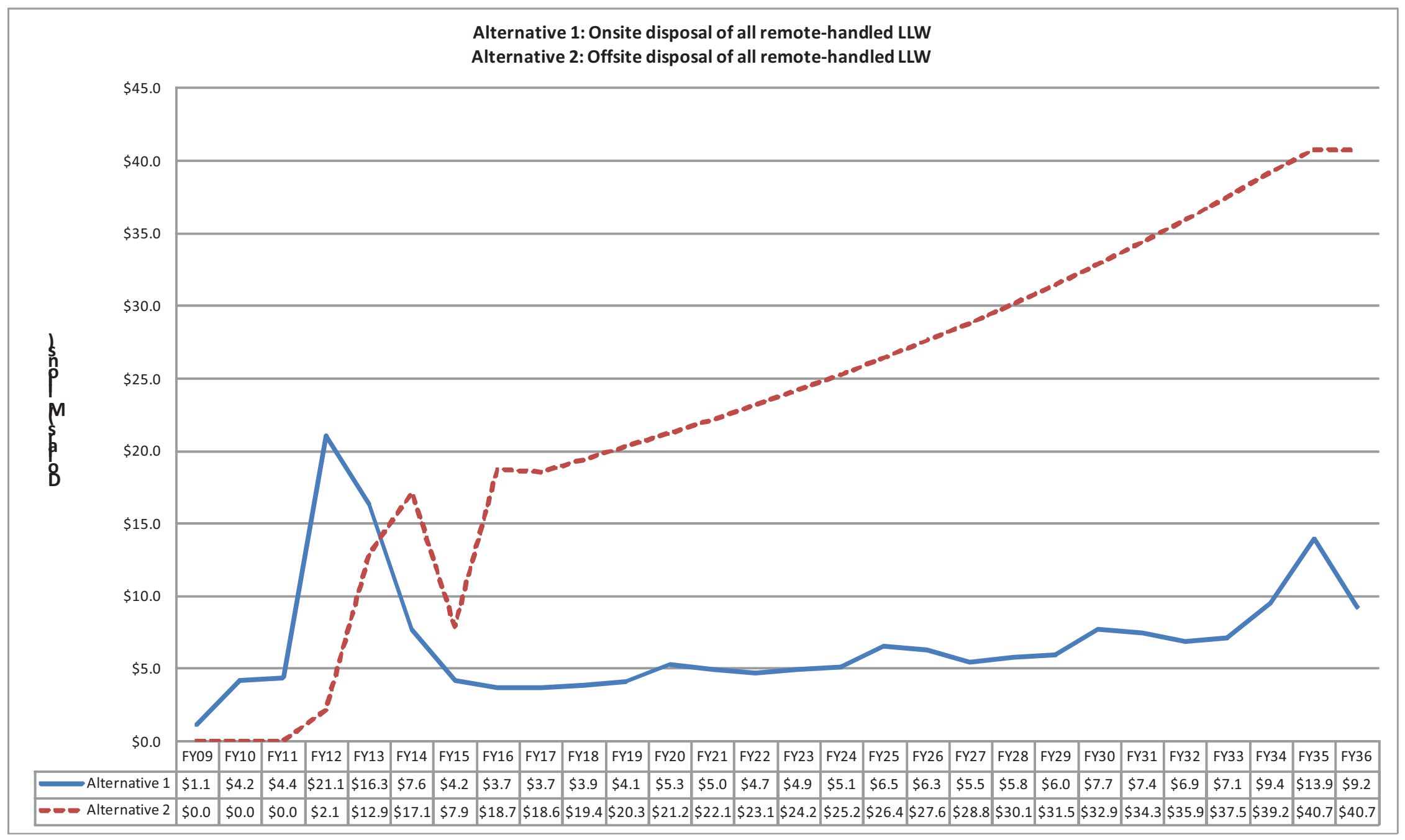

Figure 6-1. Annual project costs by disposal alternative. 


\section{REFERENCES}

10 CFR 61, 2002, Title 10, "Energy," Part 61, "Licensing Requirements for Land Disposal of Radioactive Waste," Code of Federal Regulations, Office of the Federal Register.

42 USC § 4321 et seq., 1970, "National Environmental Policy Act,” United States Code, January 1, 1970.

42 USC § 6901 et seq., 1976, "Resource Conservation and Recovery Act (Solid Waste Disposal Act)," United States Code, October 21, 1976.

42 USC $§ 9601$ et seq., 1980, "Comprehensive Environmental Response, Compensation and Liability Act of 1980 (CERCLA/Superfund)," United States Code, December 11, 1980.

DOE 1995, Programmatic Spent Nuclear Fuel Management and Idaho National Engineering Laboratory Environmental Restoration and Waste Management Programs Final Environmental Impact Statement, DOE/EIS-203-F, U.S. Department of Energy, Office of Environmental Management, August 1995.

DOE 2000, "Record of Decision for the Department of Energy's Waste Management Program: Treatment and Disposal of Low-Level Waste and Mixed Low-Level Waste; Amendment to the Record of Decision for the Nevada Test Site," 65 Federal Register 10061, February 25, 2000.

DOE 2009, Guidance Regarding Low-Level and Mixed Low-Level Waste Disposal Decisions, Memorandum, U.S. Department of Energy, Office of Environmental Management, August 21, 2009.

DOE 2009a, Mission Need Statement for the Idaho National Laboratory Remote-Handled Low-Level Waste Disposal Project, U.S. Department of Energy, June 2009.

DOE 2009b, Schedules of Key Environmental Impact Statements, U.S. Department of Energy, Office of NEPA Policy and Compliance, September 16, 2009.

DOE-NV 1999, Agreement In Principal Between the Department of Energy and the State of Nevada, DE-GM08-99NV13571, June 1999.

DOE Order 435.1, 2001, "Radioactive Waste Management," U.S. Department of Energy, August 28, 2001.

INEEL 1997, Preliminary Evaluation of Potential Locations at the Idaho National Engineering and Environmental Laboratory for a High-Level Waste Treatment and Interim Storage Facility and a Low-Level Waste Landfill, INEEL/EXT-97-01324, Revision 0, Idaho National Engineering and Environmental Laboratory, Idaho Falls, Idaho, December 1997.

INL 2006, Low-Level Waste Disposal Alternatives Analysis Report, INL/EXT-06-11601, Revision 1, Idaho National Laboratory, Idaho Falls, Idaho, September 2006. 


\section{DEFINITIONS}

$\underline{\text { Term }}$

Activated metals

Cask

Complexity

Contact-handled LLW

Closure

Curie (Ci)

Disposal

Disposal, offsite

Disposal, onsite

Fissile

Radioactive waste

\section{Definition}

Structural materials from a nuclear facility that have been subjected to neutron irradiation and contain radionuclide activation products within the matrix of the material.

A container that provides appropriate shielding and structural integrity for the transportation and/or storage of spent fuel and other radioactive materials. The cask serves several functions. It provides chemical, mechanical, thermal and radiological protection, and dissipates decay heat during handling, transport, and storage.

As applied to LLW disposal alternatives, complexity refers to the number of disposal sites, parallel construction or procurement projects, and external vendors and agencies that must be coordinated for the overall alternative to achieve all waste management objectives. External refers to organizations other than Battelle Energy Alliance, INL Site tenants, and DOE.

LLW whose external dose rate is sufficiently low as to not require additional shielding or special handling. Definitions vary among facilities but are usually expressed as a dose rate equivalent at a specific distance from the waste package. This report defines contacthandled LLW as waste having a dose rate equivalent of less than 200 $\mathrm{mrem} / \mathrm{hr}$ at contact.

Administrative and technical actions taken at a waste disposal facility at the end of its operating lifetime to assure it is left in a state that is protective of human health and the environment.

Non-SI unit of measure of the rate of decay of a radioactive material. One Curie is 37 billion disintegrations per second (Becquerel). $(1 \mathrm{Ci}=$ $3.7 \times 1010 \mathrm{~Bq}$ ) A milliCurie (abbreviated $\mathrm{mCi}$ ) is equal to onethousandth of a Curie.

Emplacement of waste in an appropriate facility without the intention of retrieval.

Disposal of the LLW or portions thereof at commercial radioactive waste disposal facilities or at DOE managed sites other than the INL.

Disposal of the LLW or portions thereof within the INL site boundary.

An isotope that will undergo nuclear fission, i.e., split into two or more lighter materials, upon absorbing a thermal (slow) neutron. The three primary fissile materials are uranium-233, uranium-235, and plutonium-239.

Solid, liquid, and gaseous materials from nuclear operations that are radioactive or become radioactive and for which there is no further use. 
$\underline{\text { Term }}$

Radioactive waste, low-level

(LLRW or LLW)

rem

Remote-handled LLW

Risk

Special nuclear material

Transuranic waste

\section{Definition}

LLRW is waste that satisfies the definition of LLRW in the Low-Level Radioactive Waste Policy Amendments Act (LLRWPAA) of 1985. The LLRWPAA defines LLRW as "radioactive material that (A) is not high-level radioactive waste, spent nuclear fuel, or byproduct material as defined in section 11e.2 of the Atomic Energy Act of 1954) and; (B) the Nuclear Regulatory Commission, consistent with existing law and in accordance with paragraph (A), classifies as low-level radioactive waste." In a sense, LLRW is defined by what it is not and consequently is the broadest category of waste. It encompasses materials that are slightly above natural radiation background levels to highly radioactive materials which require extreme caution when handling (Greater than Class C). Categorization as LLRW does not depend on the level of radioactivity it contains.

Non-SI unit of equivalent dose that measures the effects of ionizing radiation on humans. One rem is equal to 0.01 sievert. A millirem (abbreviated mrem) is equal to one-thousandth of a rem.

LLW that requires special tools, equipment, and procedures for handling to minimize personnel exposure. Definitions vary among facilities but are usually expressed as a dose rate equivalent at a specific distance from the waste package. This report defines remotehandled LLW as waste having a dose rate equivalent of equal to or greater than $200 \mathrm{mrem} / \mathrm{hr}$ at contact.

An analysis of possible events, their probabilities of occurrence, and their potential consequences for the disposal option being evaluated.

Special nuclear material is defined in 10 CFR 20.1003 as "(1) Plutonium, uranium-233, uranium enriched in the isotope 233 or in isotope 235, and any other material that the NRC, pursuant to the provisions of section 51 of the Atomic Energy Act, determines to be special nuclear material, but does not include source material; (2) or any material artificially enriched by any of the foregoing but does not include source material." Special nuclear material is important in the fabrication of weapons grade materials and as such has strict licensing and handling controls.

Transuranic waste is radioactive waste containing more than 100 nanocuries $(3,700$ becquerels) of alpha-emitting transuranic isotopes per gram of waste, with half-lives greater than 20 years, except for:

(1) High-level radioactive waste;

(2) Waste that the Secretary of Energy has determined, with the concurrence of the Administrator of the Environmental Protection Agency, does not need the degree of isolation required by the 40 CFR Part 191 disposal regulations; or

(3) Waste that the NRC has approved for disposal on a case-by-case basis in accordance with 10 CFR Part 61. 
$\underline{\text { Term }}$

Waste acceptance criteria

Waste inventory

Waste generator

\section{Definition}

A document that specifies the quantitative or qualitative criteria that must be met for waste to be accepted by the operator of a specific repository for disposal, or by the operator of a storage facility for storage. Waste acceptance requirements might include, for example, restrictions on the radionuclide concentration or the total activity of particular radionuclides (or types of radionuclide) in the waste or requirements concerning the waste form or waste package.

Quantity, radionuclides, activity and waste form characteristics of wastes for which an operator is responsible.

The operating organization of a facility or activity that generates waste. 
Appendix A

Regulatory Evaluation 
A-2 


\section{Appendix A \\ Regulatory Evaluation}

This appendix presents and evaluates the regulatory framework for remote-handled LLW disposal. Requirements that apply to commercial and DOE facilities are examined. The key areas of regulatory focus are the licensing of commercial facilities, DOE regulation of its disposal facilities, and compliance with NEPA.

\section{A-1. REGULATORY REQUIREMENTS FOR COMMERCIAL DISPOSAL OF IDAHO NATIONAL LABORATORY REMOTE-HANDLED LOW-LEVEL WASTE}

Under the Atomic Energy Act of 1954 (Public Law 83-703), as amended, regulation of non-DOE managed radioactive materials is the responsibility of NRC. NRC can agree to delegate its authority to a state that can demonstrate that it has qualified regulatory program in place. For INL's interests, Texas, Utah, and Washington are NRC agreement states and administer the LLW disposal program; Idaho has not been delegated authority.

The LLRWPAA (Public Law 99-240) includes incentives and milestones for states to establish disposal capacity for waste generated within their borders. This statute specified that DOE is responsible for LLW generated by its facilities, from Navy decommissioned nuclear power ships, from the government's research and development related to atomic weapons, and for waste with concentrations that exceed the limits established for Class $\mathrm{C}$ radioactive waste. States are responsible for other waste generated by the federal government. This Act encourages development of regional compacts among states for development of disposal capacity. DOE Order 435.1 governs DOE waste management and provides that DOE waste may be disposed of in a commercial landfill with approval from the field office after notification to DOE Headquarters and consultation with DOE Environment, Safety, and Health. However, compact or commercial facilities are not obligated to accept DOE waste.

The Northwest Compact, formed pursuant to the LLRWPAA in December 1985, includes the member states of Washington, Alaska, Hawaii, Idaho, Montana, Oregon, Utah, and Wyoming. The first regional disposal facility was located on the Hanford Site and is currently operated by U.S. Ecology. In 1988, the Energy Solutions facility in Clive, Utah was opened but limited to disposal of low-activity, naturally occurring, radioactively contaminated waste. In 1995, the Northwest Compact agreed that the facility could take large-volume soil, soil-like materials, and debris, including waste generated from operations and routine cleanups.

The requirements for siting and operation of commercial disposal facilities are established by NRC. 10 CFR 61 contains the provisions for regulation of commercial LLW from generation through disposal, including closure of disposal facilities. The regulations include performance objectives and technical requirements for waste classification, site suitability, facility design, operations, closure, and monitoring. 10 CFR 51 provides the regulations for NRC's compliance with NEPA for LLW facilities. The NEPA evaluation is conducted in conjunction with the licensing activity.

Neither DOE Order 435.1 nor 10 CFR 61 requires artificial or clay liners for LLW land disposal. These RCRA-type liners are traditionally not used for LLW disposal facilities because, since development of 10 CFR 61, the concept of "controlled release" has been understood to be an effective approach for managing LLW disposal. In reference to 10 CFR 61.51, Disposal Site Design, item (6), the Final EIS on 10 CFR 61, NUREG-0945, Vol. 1, p. 5-14, states that allowing for some leakage is actually desirable: 
"Reducing the contact time of water with the waste by using freely draining granular backfill should be considered. In addition, the accumulation of water in the disposal unit (the bathtub effect) must be avoided. This can normally be accomplished if the bottom of the disposal unit can drain at least as readily as water can infiltrate into the disposal unit through the cover or sides...."

Relying on an artificial or clay liner also contradicts a technical requirement in 10 CFR 61 to not become dependent on a design feature that could require long-term maintenance. Specifically, in the original Federal Register notification for 10 CFR 61 (47 FR 57450), the first paragraph states:

"The Commission takes exception to any design which relies on a leachate collection and treatment system to reduce migration. Such a design is expected to result in a requirement for continued active site maintenance, therefore violating the performance objective in [10 CFR Part] 61.44."

LLW is defined under LLWPAA and NRC regulations as waste that is not transuranic waste, spent nuclear fuel, by-product material, or high-level waste. LLW slated for commercial disposal is classified as Class A, Class B, or Class C. These classes involve increasingly stringent requirements for waste form and stability and measures to protect against inadvertent intrusion. Waste that involves higher concentrations and different and more stringent disposal methods from Class $\mathrm{C}$ is not generally acceptable for near-surface disposal unless approved by NRC. This waste is referred to as greater-than-Class-C waste.

\section{A-2. REGULATORY REQUIREMENTS FOR DISPOSAL OF REMOTE-HANDLED LOW-LEVEL WASTE AT A DEPARTMENT OF ENERGY FACILITY}

DOE Order 435.1 governs LLW management at DOE facilities. DOE Order 435.1 includes the following performance objectives for a LLW disposal facility:

- Dose to representative members of the public shall not exceed $25 \mathrm{mrem}(0.25 \mathrm{mSv})$ in a year total effective dose equivalent from all exposure pathways, excluding the dose from radon and its progeny in air

- Dose to representative members of the public via the air pathway shall not exceed $10 \mathrm{mrem}$ $(0.10 \mathrm{mSv})$ in a year total effective dose equivalent, excluding the dose from radon and its progeny

- Release of radon shall be less than an average flux of $20 \mathrm{pCi} / \mathrm{m}^{2} / \mathrm{s}\left(0.74 \mathrm{~Bq} / \mathrm{m}^{2} / \mathrm{s}\right)$ at the surface of the disposal facility. Alternatively, a limit of $0.5 \mathrm{pCi} / 1(0.0185 \mathrm{~Bq} / \mathrm{l})$ of air may be applied at the boundary of the facility.

Each disposal facility conducts a performance assessment that includes calculations for a 1,000-year period after closure of potential doses to representative future members of the public and potential releases from the facility. The performance assessment is then used to establish the limits on the concentrations of radionuclides that can be disposed of.

A Disposal Authorization Statement must be obtained from DOE Headquarters before construction of a new disposal facility. This statement is based on a review of the facility's design and documentation. It provides the specific limits for design, construction, operation, and closure. 
DOE uses a definition of LLW similar to NRC: "Low-level radioactive waste is radioactive waste that is not high-level radioactive waste, spent nuclear fuel, transuranic waste, byproduct material (as defined in Section 11e.(2) of the Atomic Energy Act of 1954, as amended), or naturally occurring radioactive material." However, DOE's system does not provide further waste classifications.

Decisions regarding disposal at facilities regulated by DOE are subject to NEPA evaluation. DOE has codified its NEPA compliance rules in 10 CFR 1021. Previous DOE NEPA reviews and decisions for actions proposed for LLW waste management can be used to support the NEPA process for INL LLW disposal plans after FY 2009.

Impacts of disposal of LLW offsite and onsite at INL have been evaluated in two EISs: (1) Programmatic Spent Nuclear Fuel and Idaho National Engineering Laboratory Environmental Restoration and Waste Management EIS (DOE 1995), and (2) the Waste Management Programmatic EIS (DOE 1997). These EISs address LLW in general without distinguishing between remote-handled and contact-handled LLW. The volume and characteristics of the INL LLW in these EISs were based on conservative estimates that exceed current LLW volume projections and inventories. NEPA analysis for the decision on disposal of INL's LLW will tier from the decisions made in these EISs by referencing the affected environment and the impacts analysis for offsite and onsite disposal. Onsite disposal of LLW was selected in the record of decision for the Programmatic Spent Nuclear Fuel and Idaho National Engineering Laboratory Environmental Restoration Waste Management EIS (60 FR 28680). The decision for LLW in the Waste Management Programmatic EIS expanded INL options. That ROD identifies Hanford and NTS as regional disposal sites, with onsite disposal taking place at INL, Savannah River Site, Oak Ridge National Laboratory, and Los Alamos National Laboratory (65 FR 10061).

An EA is recommended to address the project-specific impacts posed by construction, operation, and end-state of a new onsite disposal facility or by use of offsite disposal capacity for remote-handled LLW. The EA would document the NEPA analysis and decisions from the EISs and assess the significance of the impacts for the alternatives under consideration.

Continued use of existing facilities for the same purpose and types of waste during the interim, as authorized by the previous RODs and as reviewed in supplemental analyses, would not be subject to further NEPA review.

Waste that has no path to disposal and characteristics similar to waste classified as greater-thanClass-C under the NRC definitions is not addressed in the two EISs mentioned above. Under the Low-Level Radioactive Waste Policy Amendments Act of 1985, the federal government is responsible for the disposal of greater-than-Class-C low-level waste generated by licensees of NRC and the agreement states. DOE was identified as the federal agency responsible for this effort. In February 1989, a report to Congress from DOE (1990) stated that it plans to accept and manage limited quantities of greater-thanClass-C low-level waste until a disposal facility is developed.

DOE has issued a Notice of Intent to prepare an EIS specifically to address disposal of greaterthan-Class-C LLW generated from facilities licensed by NRC and waste with similar characteristics generated by DOE (72 FR 40135). Decisions on future management of this waste will be made pursuant to this EIS. It is assumed that the remote-handled LLW disposal capacity project will not be impacted by the greater-than-Class-C EIS because INL's remote-handled LLW is not included in the inventory of waste to be analyzed under the greater-than-Class-C EIS. 


\section{A-3. REFERENCES}

10 CFR 51, 2002, Title 10, "Energy," Part 51, "Environmental Protection Regulations for Domestic Licensing and Related Regulatory Functions," Code of Federal Regulations, Office of the Federal Register.

10 CFR 61, 2002, Title 10, "Energy," Part 61, "Licensing Requirements for Land Disposal of Radioactive Waste," Code of Federal Regulations, Office of the Federal Register.

10 CFR 1021, 2002, Title 10, "Energy," Part 1021, "National Environmental Policy Act Implementing Procedures," Code of Federal Regulations, Office of the Federal Register.

60 FR 28680, 1995, "Record of Decision: Programmatic Spent Nuclear Fuel Management and Idaho National Engineering Laboratory Environmental Restoration and Waste Management Programs," Federal Register, U.S. Environmental Protection Agency, June 1, 1995.

65 FR 10061, 2000, "Record of Decision for the Department of Energy's Waste Management Program: Treatment and Disposal of Low-Level Waste and Mixed Low-Level Waste; Amendment to the Record of Decision for the Nevada Test Site," Federal Register, U.S. Environmental Protection Agency, February 25, 2000.

72 FR 40135, 2007, "Notice of Intent To Prepare an Environmental Impact Statement for the Disposal of Greater-Than-Class-C Low-Level Radioactive," Federal Register, U.S. Environmental Protection Agency, July 23, 2007.

DOE 1990, “1989 Annual Report on Low-Level Radioactive Waste Management Progress,” DOE/EM0006P, Washington, DC: DOE Office of Environmental Restoration and Waste Management, U.S. Department of Energy, October 1990.

DOE 1995, Programmatic Spent Nuclear Fuel Management and Idaho National Engineering Laboratory Environmental Restoration and Waste Management Programs Final Environmental Impact Statement, DOE/EIS-203-F, U.S. Department of Energy, Office of Environmental Management, August 1995.

DOE, 1997, Final Waste Management Programmatic Environmental Impact Statement for Managing Treatment, Storage, and Disposal of Radioactive and Hazardous Waste, DOE/EIS-200-F, U.S. Department of Energy, Office of Environmental Management, June 1997.

DOE Order 435.1, 2001, "Radioactive Waste Management," U.S. Department of Energy, August 28, 2001.

PL 83-703, 1954, "The Atomic Energy Act of 1954, as amended," 42 U.S.C. 201, (August 30, 1954) [established requirements for availability and dissemination of information generated by or for DOE], Public Law.

PL 99-240, 1986, “Low-Level Radioactive Waste Policy Act, Public Law, January 15, 1986. 


\section{Appendix B}

\section{Activated Metals Cask Search and Selection}


B-2 


\section{Appendix B}

\section{Activated Metals Cask Search and Selection}

The purpose of this activity was to locate all casks certified for use in interstate commerce that meet the operational requirements of transporting activated metals generated by ATR, MFC, and NRF at INL. To accomplish this task, the basic equipment interface needs of the subject facilities were determined to support a cost-effective common system. A search for acceptable casks was conducted using the RAMPAC database and guidelines provided in the DOE Office of Transportation bulletin, "Regulatory and Legislative Development Highlights," dated June 2006.

Cask criteria for the remote-handled LLW activated metals are contained in Table B-1.

Table B-1. Cask criteria.

\begin{tabular}{|c|c|c|c|c|c|}
\hline $\begin{array}{c}\text { Loaded Cask } \\
\text { Weight }^{1} \\
\text { (lb) }\end{array}$ & $\begin{array}{l}\text { Loading } \\
\text { Method }^{2}\end{array}$ & $\begin{array}{c}\text { Hard Gamma } \\
\text { Curie Capacity }\end{array}$ & $\begin{array}{c}\text { Insert } \\
\text { Dimensions }{ }^{4} \\
\end{array}$ & $\begin{array}{c}\text { Insert Weight } \\
\text { Limit }\end{array}$ & $\begin{array}{c}\text { Mode of } \\
\text { Travel }\end{array}$ \\
\hline $\begin{array}{c}\leq 80,000 \\
\text { (truck loaded) }\end{array}$ & Dry and wet & $15,000 \mathrm{R} / \mathrm{h}$ & $\begin{array}{c}\geq 96 \text {-in. height } \\
\text { and } 20 \text {-in. } \\
\text { diameter }\end{array}$ & Cask driven & $\begin{array}{l}\text { Public } \\
\text { highway }\end{array}$ \\
\hline \multicolumn{6}{|c|}{$\begin{array}{l}\text { This limit is driven by the crane capacity at the ATR canal and over the road shipping limits. } \\
\text { Two basic loading methods will be used: (1) bottom loading from a canal or water pit operations up into the cask and (2) } \\
\text { loading from hot cell operations down into the cask. } \\
\text { It is assumed that the dose rate on contact for the entire waste stream is similar to that for NRF to date: } 1 \% \text { greater than } \\
15,000 \mathrm{R} / \mathrm{hr}(30,000 \mathrm{R} / \mathrm{hr} \text { maximum) and } 9 \% \text { greater than } 7,000 \mathrm{R} / \mathrm{hr} \text {. It may be necessary to hold waste that exceeds } \\
15,000 \mathrm{R} / \mathrm{hr} \text { onsite for decay to less than } 15,000 \mathrm{R} / \mathrm{hr} \text {. } \\
\text { This insert dimension is the minimum size acceptable for NRF-activated metals waste with no sizing. }\end{array}$} \\
\hline
\end{tabular}

The approach taken to assess cask viability is as follows:

- The RAMPAC database was thoroughly researched and Type B casks that met or were close to meeting the criteria specified in Table B-1 were identified. The research focused primarily on waste casks; however, based on the advice of Ashok Kapoor (DOE Office of Transportation), fuel casks also were evaluated on the assumption that they could be recertified for waste.

- The RAMPAC data associated with these casks were compiled and are presented in Tables B-2 and B-3. These tables indicate cask viability based on the dimensions of the internal cavity. Casks transported by truck or rail were originally included, but those suited only for rail were subsequently discarded.

- Table B-4 contains a short list of those casks that met the volume criteria. These were then assessed against the weight criteria, current Certificate of Compliance $(\mathrm{C}$ of $\mathrm{C})$ status, and whether the $15,000 \mathrm{R} / \mathrm{hr}$ criteria could be met. The results of this assessment are reflected in the tables.

- Those casks that met criteria were then researched further regarding cask availability or other issues that precluded a given cask from meeting INL needs. Competition with the private sector for cask availability also was considered. 
Table B-2. Nuclear Regulatory Commission Certificates of Compliance.

\begin{tabular}{|c|c|c|c|c|c|c|}
\hline \multicolumn{5}{|c|}{ NRC Certificates of Compliance } & \multirow[b]{2}{*}{$\begin{array}{c}\text { Usable for } \\
\text { Vols. of } \\
\text { Activated Metal }\end{array}$} & \multirow[b]{2}{*}{$\begin{array}{l}\text { Cavity } \mathrm{H}^{\prime \prime} \text { x Dia" and } \\
\text { Cask Gross Weight }\end{array}$} \\
\hline $\begin{array}{l}\text { Retrieval } \\
\text { Number }\end{array}$ & Package ID Number & Rev & Package Model Number & Expiration Date & & \\
\hline 1010361 & $\mathrm{USA} / 0361 / \mathrm{B}(\mathrm{U}) \mathrm{F}-96$ & 8 & PAT-1 & $3 / 31 / 2009$ & $\mathrm{n}$ & $8 " \times 7 "$ \\
\hline 1014888 & USA/4888/B( ) & 12 & $\begin{array}{l}\text { SENTINEL-25A, LCG-25A; SENTINEL-25B, } \\
\text { LCG-25B; SENTINEL-25C, LCG-25C; } \\
\text { SENTINEL-25C3, -25D, -25E, -25F }\end{array}$ & $1 / 31 / 2007$ & $\mathrm{n}$ & $25^{\prime \prime} \times 32^{\prime \prime}$ \\
\hline 1015086 & $\mathrm{USA} / 5086 / \mathrm{B}(\mathrm{U}) \mathrm{F}$ & 12 & UNC-2600 & $2 / 28 / 2009$ & $\mathrm{n}$ & $3 \times 7 \times 96$ \\
\hline 1015149 & $\mathrm{USA} / 5149 . \mathrm{B}(\mathrm{)F}$ & 11 & $814 \mathrm{~A}$ & $10 / 1 / 2008$ & $\mathrm{n}$ & Fuel Cluster \\
\hline 1015607 & USA/5607/B( )F & 12 & $\mathrm{~T}-2$ & $10 / 1 / 2008$ & $\mathrm{n}$ & $6 \times 100$ \\
\hline 1015740 & USA/5740/B( ) & 6 & $\begin{array}{l}\text { ORNL TRU CALIFORNIUM SHIPPING } \\
\text { CONTAINER (Currently Under TIMELY } \\
\text { RENEWAL) }\end{array}$ & $7 / 31 / 2006$ & $\mathrm{n}$ & $3 " \times 6 "$ \\
\hline 1015796 & USA/5796/B(U) & 15 & 181375 AND 181361 & $8 / 31 / 2007$ & $\mathrm{n}$ & $\begin{array}{c}43.5 \times 39.75 \times 41 " \& \\
39 \times 34.25 \times 44.5^{\prime \prime}\end{array}$ \\
\hline 1015797 & USA/5797/B(U)F & 15 & $\begin{array}{l}\text { INNER HFIR UNIRRADIATED FUEL } \\
\text { ELEMENT SHIPPING CONTAINER, AND } \\
\text { OUTER HFIR UNIRRADIATED FUEL } \\
\text { ELEMENT SHIPPING CONTAINER } \\
\end{array}$ & $9 / 30 / 2007$ & $\mathrm{n}$ & 25 "OD x $45 " \mathrm{H}$ \\
\hline 1015805 & USA/5805/B( ) & 23 & CNS 3-55 & $10 / 1 / 2008$ & $\mathrm{y}$ & $\begin{array}{c}111 \times 36 \\
(70,000 \mathrm{lbs})\end{array}$ \\
\hline 1015830 & USA/5830/B( ) & 10 & SNAP-21 & $10 / 1 / 2008$ & $\mathrm{n}$ & $52 " \mathrm{D} \times 68 " \mathrm{H}$ \\
\hline 1015862 & USA/5862/B( ) & 9 & SENTINEL-100F & $10 / 1 / 2008$ & $\mathrm{n}$ & $45.5 " \mathrm{H} \times 24.5^{\prime \prime}$ \\
\hline 1015926 & USA/5926/B( )F & 18 & GE-100 & $5 / 31 / 2008$ & $\mathrm{n}$ & $75 / 8 " \times 10^{\prime \prime}$ \\
\hline 1015939 & USA/5939/B( )F & 32 & 1500 & $10 / 1 / 2008$ & $\mathrm{n}$ & $7 " \times 25 "$ \\
\hline 1015957 & USA/5957/B( )F & 28 & BMI-1 & $10 / 1 / 2008$ & $\mathrm{n}$ & $54 \times 15$ \\
\hline 1015979 & USA/5979/B( ) & 11 & 5979 & $10 / 1 / 2008$ & $\mathrm{n}$ & $24 " \mathrm{D}$ \\
\hline 1015984 & USA/5984/B( ) & 7 & 5984 & $8 / 31 / 2007$ & $\mathrm{n}$ & $28 " x 43 "$ \\
\hline 1016058 & USA/6058/B( )F & -- & B-3 (TERMINATION LETTER, January 4, 2006) & --------- & $\mathrm{n}$ & Termination Letter \\
\hline 1016280 & USA/6280/B( ) & -- & $\begin{array}{l}\text { A-0109 IRRADIATOR IN A-0117 OVERPACK } \\
\text { (TERMINATION LETTER, January 31, 2005) }\end{array}$ & --------- & $\mathrm{n}$ & Termination Letter \\
\hline 1016346 & USA/6346/B( )F & -- & $\begin{array}{l}\text { FSV-1 (TERMINATION LETTER, April 19, } \\
2006)\end{array}$ & ---------- & $\mathrm{n}$ & Termination Letter \\
\hline 1016400 & USA/6400/B( )F & 27 & 6400 Super Tiger & $11 / 30 / 2007$ & $\mathrm{y}$ & $\begin{array}{c}76^{\prime \prime} \times 76^{\prime \prime} \times 172^{\prime \prime} \\
(45,000 \mathrm{lbs})\end{array}$ \\
\hline 1016574 & USA/6574/B( ) & 31 & $3-82 B$ & $\begin{array}{c}10 / 1 / 2008 \\
\text { (no renewal per } \\
\text { EM/OT-006) }\end{array}$ & $\mathrm{n}$ & $66.25^{\prime \prime} \times 74.5^{\prime \prime}$ \\
\hline 1016613 & USA/6613/B(U)-96 & 12 & 702 & $6 / 30 / 2008$ & $\mathrm{n}$ & $2.26^{\prime \prime} \times 3.25^{\prime \prime}$ \\
\hline 1016642 & $\mathrm{USA} / 6642 / \mathrm{B}(\mathrm{)}$ & 7 & 4.5-TON CF & $2 / 28 / 2007$ & $\mathrm{n}$ & $4 " \times 63 / 8 "$ \\
\hline 1016703 & USA/6703/B( ) & 7 & RG-1 & $9 / 30 / 2008$ & $\mathrm{n}$ & $18^{\prime \prime} \times 14^{\prime \prime}$ \\
\hline 1016786 & USA/6786/B( ) & 8 & URIPS-8A AND URIPS-8B & $10 / 1 / 2008$ & $\mathrm{n}$ & $28.5^{\prime \prime} \times 19.14 "$ \\
\hline 1019001 & USA/9001/B( )F & 39 & IF-300 & $10 / 1 / 2008$ & $\mathrm{n}$ & $\begin{array}{l}180 \times 37 \\
\text { (cavity split into } 2 \\
\text { compartments; } \\
140,000 \mathrm{lbs} \text { ) }\end{array}$ \\
\hline 1019010 & USA/9010/B( )F & 41 & NLI-1/2 & $10 / 1 / 2008$ & $\mathrm{n}$ & $125 / 8^{\prime \prime} \times 178^{\prime \prime}$ \\
\hline 1019015 & USA/9015/B( )F & 21 & TN-8 AND TN-8L & $10 / 1 / 2008$ & $\mathrm{n}$ & $\begin{array}{l}230 \mathrm{~mm} \times 230 \mathrm{~mm} \times \\
4280 \mathrm{~mm} \mathrm{~L}\end{array}$ \\
\hline 1019016 & USA/9016/B( )F & 14 & TN-9 & $10 / 1 / 2008$ & $\mathrm{n}$ & $\begin{array}{c}1718 \mathrm{~mm} \times 5756 \mathrm{~mm} \\
(7 \text { compartments } \\
150 \mathrm{~mm} \times 150 \mathrm{~mm} \times \\
4520 \mathrm{~mm}) \\
\end{array}$ \\
\hline 1019023 & USA/9023/B( )F & 9 & NLI-10/24 & $7 / 31 / 2008$ & $\mathrm{y}$ & $\begin{array}{c}179 \times 45 \\
(194,000 \mathrm{lbs}) \\
\end{array}$ \\
\hline 1019027 & USA/9027/B(U)-85 & 17 & 741-OP (Currently Under TIMELY RENEWAL) & $2 / 28 / 2006$ & $\mathrm{n}$ & $32 " \mathrm{x} 19 " \mathrm{M} 18.5 "$ \\
\hline 1019030 & USA/9030/B( ) & 10 & MW-3000 AND SENTINEL-8 & $10 / 1 / 2008$ & $\mathrm{n}$ & $\begin{array}{c}24 \text { OD } \times 23 ; 24 \text { OD x } \\
25\end{array}$ \\
\hline 1019035 & USA/9035/B(U)-96 & 19 & 680-OP & $6 / 30 / 2010$ & $\mathrm{n}$ & $32 " \times 19 " \times 181 / 2 "$ \\
\hline 1019036 & USA/9036/B(U)-85 & 10 & C-1 & $10 / 31 / 2006$ & $\mathrm{n}$ & $9 " \times 7.5^{\prime \prime} \times 7.5^{\prime \prime}$ \\
\hline 1019056 & USA/9056/B(U) & 12 & SPEC 2-T & $4 / 30 / 2010$ & $\mathrm{n}$ & $\begin{array}{c}133 / 8^{\prime \prime} \text { x } 411 / 16^{\prime \prime} \text { x } 4 \\
3 / 8 "\end{array}$ \\
\hline 1019067 & USA/9067/B( )F & 7 & BCL-3 & $9 / 30 / 2007$ & $\mathrm{n}$ & $10.5 " \mathrm{H} \times 4.5 " \mathrm{D}$ \\
\hline 1019068 & USA/9068/B( )F & -- & $\begin{array}{l}\text { BCL-2 (TERMINATION LETTER, November } \\
16,2004)\end{array}$ & --------- & $\mathrm{n}$ & Termination Letter \\
\hline 1019070 & USA/9070/B(U) & 17 & $\mathrm{~N}-55$ & $1 / 31 / 2010$ & $\mathrm{n}$ & $34.5 " \mathrm{H} \times 24 " \mathrm{D}$ \\
\hline
\end{tabular}


Table B-2 (continued).

\begin{tabular}{|c|c|c|c|c|c|c|}
\hline \multicolumn{5}{|c|}{ NRC Certificates of Compliance } & \multirow[b]{2}{*}{$\begin{array}{c}\text { Usable for } \\
\text { Vols. of } \\
\text { Activated Metal }\end{array}$} & \multirow[b]{2}{*}{$\begin{array}{c}\text { Cavity H" x Dia" and } \\
\text { Cask Gross Weight }\end{array}$} \\
\hline $\begin{array}{l}\text { Retrieval } \\
\text { Number }\end{array}$ & Package ID Number & Rev & Package Model Number & Expiration Date & & \\
\hline 1019081 & USA/9081/B( ) & 14 & CNS $1-13 \mathrm{C}$ (shielding is $5 " \mathrm{~Pb}$ ) & \begin{tabular}{|c|}
$1 / 31 / 2008$ \\
not renewable per \\
EM/OT-006 \\
\end{tabular} & $\mathrm{n}$ & $\begin{array}{c}54 \times 26.5 \\
(26,000 \mathrm{lbs})\end{array}$ \\
\hline 1019098 & USA/9098/B( ) & -- & $\begin{array}{l}\text { CI-20WC-2 AND CI-20WC-2A } \\
\text { (TERMINATION LETTER, January 4, 2006) }\end{array}$ & --------- & $\mathrm{n}$ & Termination Letter \\
\hline 1019099 & USA/9099/B(U)F-85 & 10 & 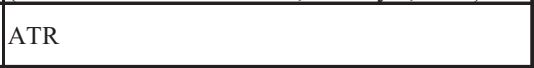 & $1 / 31 / 2009$ & $\mathrm{n}$ & $\begin{array}{c}697 / 16 \times 2613 / 16 \times 6 \\
15 / 16^{\prime \prime} \\
\end{array}$ \\
\hline 1019102 & USA/9102/B( ) & 10 & NPI-20WC-6 & $10 / 1 / 2008$ & $\mathrm{n}$ & \begin{tabular}{|c|}
$48 " \mathrm{D}$ \\
\end{tabular} \\
\hline 1019132 & USA/9132/B(M)F & 15 & $\mathrm{~T}-3$ & $4 / 30 / 2011$ & $\mathrm{n}$ & $147 \times 8$ \\
\hline 1019148 & USA/9148/B(U)-85 & 7 & 770 & $3 / 31 / 2008$ & $\mathrm{n}$ & $\begin{array}{l}23 " \mathrm{~L} \times 24 " \mathrm{~W} \times \\
19.75 " \mathrm{H}\end{array}$ \\
\hline 1019150 & $\mathrm{USA} / 9150 / \mathrm{B}(\mathrm{U})-85$ & 6 & PAT-2 (Currently Under TIMELY RENEWAL) & $7 / 31 / 2006$ & $\mathrm{n}$ & $14 " \mathrm{H} \times 15 " \mathrm{D}$ \\
\hline 1019152 & USA/9152/B( )F & 14 & CNS $1-13 \mathrm{C}$ II (sheilding is $5 " \mathrm{~Pb}$ ) & \begin{tabular}{|c|}
$10 / 1 / 2008$ \\
not renewable per \\
EM/OT-006 \\
\end{tabular} & $\mathrm{n}$ & $\begin{array}{c}45 \times 26 \\
(27,000 \mathrm{lbs})\end{array}$ \\
\hline 1019157 & USA/9157/B(U)-85 & 11 & IR-100 & $9 / 30 / 2009$ & $\mathrm{n}$ & $\begin{array}{c}8.87 " \mathrm{~L} \times 4.5 " \mathrm{~W} \times 8.5 " \\
\mathrm{H} \\
\end{array}$ \\
\hline$\underline{1019165}$ & USA/9165/B(U) & -- & 855 (TERMINATION LETTER, August 5, 2005) & --------- & $\mathrm{n}$ & Termination Letter \\
\hline 1019168 & USA/9168/B(U) & 15 & $\begin{array}{l}\text { CNS 8-120B } \\
(3.35 " \mathrm{~Pb} \text { shielding })\end{array}$ & $\begin{array}{c}6 / 30 / 2010 \\
\text { COC renewable }\end{array}$ & $\mathrm{n}$ & $\begin{array}{c}75 \times 62 \\
(74,000 \mathrm{lbs}) \\
\end{array}$ \\
\hline 1019184 & USA/9184/B(U) & 6 & PAS-1 & $7 / 31 / 2009$ & $\mathrm{n}$ & 20.5 "OD x 23.4" OH \\
\hline 1019185 & USA/9185/B(U)-85 & 6 & OP-100 & $12 / 31 / 2008$ & $\mathrm{n}$ & $\begin{array}{c}8.87 " \mathrm{~L} \text { x } 4.5 " \mathrm{~W} \times \\
8.5 " \mathrm{H}\end{array}$ \\
\hline 1019187 & USA/9187/B(U)-85 & 6 & 865 & $12 / 31 / 2008$ & $\mathrm{n}$ & 5 "OD x 12.25"L \\
\hline 1019200 & USA/9200/B(M)F & 11 & $\begin{array}{l}\text { 125-B (Currently Under TIMELY RENEWAL) } \\
\left(3.88^{\prime \prime} \mathrm{Pb} \text { annulus) }\right.\end{array}$ & $6 / 30 / 2011$ & y & $\begin{array}{c}192 \times 51 \\
(181,500 \mathrm{lbs}) \\
\end{array}$ \\
\hline 1019204 & USA/9204/B(U)-85 & 11 & $\begin{array}{l}\text { CNS } 10-160 \mathrm{~B} \\
(1 " \mathrm{~Pb} \text { shielding })\end{array}$ & $10 / 31 / 2010$ & $\mathrm{n}$ & $77 \times 68$ \\
\hline 1019208 & USA/9208/B( ) & 15 & $\begin{array}{l}10-142 \\
(3.5 " \mathrm{~Pb} \text { shielding })\end{array}$ & $\begin{array}{c}8 / 31 / 2007 \\
\text { (not renewable } \\
\text { beyond } \\
10 / 1 / 2008 \text { ) } \\
\end{array}$ & $\mathrm{n}$ & $\begin{array}{c}72 \times 66 \\
(68,000 \mathrm{lbs})\end{array}$ \\
\hline 1019210 & USA/9210/B( ) & -- & $\begin{array}{l}\text { 10-135B (TERMINATION LETTER, January 18, } \\
2005)\end{array}$ & ---------- & $\mathrm{n}$ & Termination Letter \\
\hline$\underline{1019212}$ & USA/9212/B(M)F-85 & 3 & RH-TRU 72-B & $2 / 28 / 2010$ & $\mathrm{n}$ & $130 " \mathrm{~L}$ x 32"OD \\
\hline$\underline{1019215}$ & $\mathrm{USA} / 9215 / \mathrm{B}(\mathrm{U})$ & 7 & NPI-20WC-6 MKII & $5 / 31 / 2008$ & $\mathrm{n}$ & $24 " \mathrm{D}$ \\
\hline 1019216 & USA/9216/B( )F & 9 & $\begin{array}{l}\text { CNS } 1-13 \mathrm{G} \\
\left(5^{\prime \prime} \mathrm{Pb} \text { shielding }\right)\end{array}$ & $\begin{array}{c}1 / 31 / 2008 \\
\text { cannot use past } \\
10 / 1 / 2008 \\
\end{array}$ & $\mathrm{n}$ & $54 \times 26$ \\
\hline 1019218 & USA/9218/B(U)F-85 & 18 & TRUPACT-II & $8 / 31 / 2009$ & $\mathrm{n}$ & 75"H 73" D \\
\hline 1019225 & USA/9225/B(U)F-96 & 40 & NAC-LWT & $2 / 28 / 2010$ & $\mathrm{n}$ & $178 " \mathrm{~L}$ x 13.4" D \\
\hline 1019226 & USA/9226/B(U)F-85 & 1 & $\begin{array}{l}\mathrm{GA}-4 \\
\left(2.6^{\prime \prime} \mathrm{Du}\right)\end{array}$ & $\begin{array}{c}10 / 31 / 2008 \\
\text { (renewable per } \\
\text { EM/OT-006 } \\
\end{array}$ & y & $\begin{array}{c}4 \text { compartments } \\
8.8 \text { " X 167" L each } \\
(55,000 \mathrm{lbs}) \\
\end{array}$ \\
\hline 1019228 & USA/9228/B(U)F-96 & 23 & $\begin{array}{l}\text { GE } 2000 \\
(4 " \mathrm{~Pb} \text { shielding })\end{array}$ & $\begin{array}{c}5 / 31 / 2011 \\
\text { (is renewable) } \\
\end{array}$ & $\mathrm{n}$ & $\begin{array}{c}54 \times 26 \\
(33,550 \mathrm{lbs}) \\
\end{array}$ \\
\hline$\underline{1019233}$ & USA/9233/B(U) & 7 & TN-RAM & $4 / 30 / 2010$ & y & $\begin{array}{c}111 \times 35 \\
(80,000 \mathrm{lbs}) \\
\end{array}$ \\
\hline 1019234 & $\mathrm{USA} / 9234 / \mathrm{B}(\mathrm{U}) \mathrm{F}$ & 19 & NCI-21PF-1 & $12 / 31 / 2008$ & $\mathrm{n}$ & $30 "$ \\
\hline 1019235 & USA/9235/B(U)F-96 & 9 & NAC-STC & $3 / 31 / 2009$ & y & $\begin{array}{c}165 \times 71 \\
(260,000 \mathrm{lbs}) \\
\end{array}$ \\
\hline $1019235 \mathrm{~B}$ & USA/9235/B(U)F-85 & 8 & $\begin{array}{l}\text { NAC-STC (EXPIRATION CUT SHORT FROM } \\
3 / 31 / 2009 \text { BY REV 9) } \\
\end{array}$ & $4 / 30 / 2007$ & y & $\begin{array}{c}165 \times 71 \\
(260,000 \mathrm{lbs}) \\
\end{array}$ \\
\hline 1019248 & USA/9248/AF & 18 & SP-1, SP-2, AND SP-3 & $2 / 28 / 2009$ & $\mathrm{n}$ & $\begin{array}{c}111 / 2 " \text { x } 18 " x 179 \\
1 / 2 " \mathrm{~L} \\
\end{array}$ \\
\hline 1019250 & USA/9250/B(U)F-85 & 9 & $5 \times 22$ & $3 / 31 / 2008$ & $\mathrm{n}$ & 5"ID x $22 " \mathrm{H}$ \\
\hline 1019253 & USA/9253/B(U)F-85 & 10 & TN-FSV & $5 / 31 / 2009$ & $\mathrm{n}$ & $199 \times 18$ \\
\hline$\underline{1019255}$ & USA/9255/B(U)F-85 & 9 & $\begin{array}{l}\text { NUHOMS MP187 MULTI-PURPOSE CASK } \\
(4 " \mathrm{~Pb} \text { shielding) }\end{array}$ & $\begin{array}{l}10 / 31 / 2008 \\
\text { renewable }\end{array}$ & y & $\begin{array}{c}187 \times 68 \\
(282,000 \mathrm{lbs}) \\
\end{array}$ \\
\hline 1019258 & $\mathrm{USA} / 9258 / \mathrm{B}(\mathrm{U})-96$ & 2 & $\mathrm{~F}-294$ & $12 / 31 / 2008$ & $\mathrm{n}$ & $193 / 4 " \mathrm{H} 11$ 1/2"D \\
\hline
\end{tabular}


Table B-2. (continued).

\begin{tabular}{|c|c|c|c|c|c|c|}
\hline \multicolumn{5}{|c|}{ NRC Certificates of Compliance } & \multirow[b]{2}{*}{$\begin{array}{c}\text { Usable for } \\
\text { Vols. of } \\
\text { Activated Metal }\end{array}$} & \multirow[b]{2}{*}{$\begin{array}{l}\text { Cavity H" x Dia" and } \\
\text { Cask Gross Weight }\end{array}$} \\
\hline $\begin{array}{l}\text { Retrieval } \\
\text { Number }\end{array}$ & Package ID Number & Rev & Package Model Number & Expiration Date & & \\
\hline$\underline{1019261}$ & USA/9261/B(U)F-85 & 4 & HI-STAR 100 SYSTEM & $3 / 31 / 2009$ & $\mathrm{y}$ & $\begin{array}{l}\text { unknown (internal } \\
\text { MPC specs not listed) } \\
\quad(282,000 \mathrm{LBS})\end{array}$ \\
\hline 1019263 & USA/9263/B(U)-96 & 4 & SPEC-150 & $6 / 30 / 2010$ & $\mathrm{n}$ & $\begin{array}{c}5.4 " \mathrm{~W} \times 5.6 " \mathrm{H} \times \\
14.5 " \mathrm{~L} \\
\end{array}$ \\
\hline$\underline{1019269}$ & USA/9269/B(U)-85 & 4 & $650 \mathrm{~L}$ & $11 / 30 / 2010$ & $\mathrm{n}$ & $\begin{array}{c}10 " \mathrm{Lx} 13.25 " \mathrm{Hx} 8.25 " \\
\mathrm{~W} \\
\end{array}$ \\
\hline$\underline{1019270}$ & USA/9270/B(U)F-85 & 1 & $\begin{array}{l}\text { UMS UNIVERSAL TRANSPORT CASK } \\
\text { PACKAGE }\end{array}$ & $10 / 31 / 2007$ & $\mathrm{y}$ & $\begin{array}{c}192 \times 67 \\
(256,000 \mathrm{lbs}) \\
\end{array}$ \\
\hline 1019276 & USA/9276/B(U)F-85 & 2 & $\begin{array}{l}\text { FUELSOLUTIONS TS125 TRANSPORTATION } \\
\text { PACKAGE }\end{array}$ & $9 / 30 / 2007$ & $\mathrm{y}$ & $\begin{array}{c}193 " \mathrm{~L} 66.88 " \mathrm{D} \\
(285,000 \mathrm{lbs})\end{array}$ \\
\hline 1019277 & USA/9277/B(U)F & 3 & FSV-1 UNIT 3 & $10 / 1 / 2008$ & $\mathrm{n}$ & $187 \times 17$ \\
\hline$\underline{1019279}$ & USA/9279/B(U)F-85 & 4 & HALFPACT WASTE SHIPPING CONTAINER & $10 / 31 / 2010$ & $\mathrm{n}$ & $\begin{array}{c}\text { 92"H 74"D } \\
\text { TRU Program Cask }\end{array}$ \\
\hline 1019282 & $\mathrm{USA} / 9282 / \mathrm{B}(\mathrm{U})-96$ & 1 & SPEC-300 & $4 / 30 / 2010$ & $\mathrm{n}$ & 26"Lx14"Wx15"H \\
\hline 1019283 & USA/9283/B(U)-85 & 1 & OPL-660 AND OP-660 & $6 / 30 / 2008$ & $\mathrm{n}$ & $\begin{array}{c}127 / 8 " \mathrm{~L} \text { x } 51 / 4 " \mathrm{~W} \text { x } \\
95 / 8 " \mathrm{H} \\
\end{array}$ \\
\hline 1019284 & $\mathrm{USA} / 9284 / \mathrm{B}(\mathrm{U}) \mathrm{F}-85$ & 4 & $\begin{array}{l}\text { ESP-30X PROTECTIVE SHIPPING PACKAGE } \\
\text { FOR 30-INCH UF6 CYLINDERS }\end{array}$ & $5 / 31 / 2010$ & $\mathrm{n}$ & 30 7/8"D 82 5/8"L \\
\hline 1019287 & USA/9287/B(U)-85 & 1 & STERIGENICS EAGLE & $12 / 31 / 2009$ & $\mathrm{n}$ & $103 / 4 " \mathrm{D}$ \\
\hline 1019288 & USA/9288/B(U)F-96 & 7 & CHT-OP-TU & $3 / 31 / 2010$ & $\mathrm{n}$ & $\begin{array}{c}45 " \mathrm{~W} \times 45 " \mathrm{~L} \times 62 " \mathrm{H} \\
(4 \text { internal sleeves } \\
10 " \mathrm{ID}) \\
\end{array}$ \\
\hline $1019288 \mathrm{~B}$ & USA/9288/B(U)F-85 & 6 & $\begin{array}{l}\text { CHT-OP-TU (EXPIRATION DATE CUT } \\
\text { SHORT FROM 3/31/2010 BY REVISION 7) }\end{array}$ & $4 / 30 / 2007$ & $\mathrm{n}$ & $45 " \mathrm{~W}$ x $45 " \mathrm{~L}$ x $62 " \mathrm{H}$ \\
\hline$\underline{1019289}$ & $\mathrm{USA} / 9289 / \mathrm{B}(\mathrm{U}) \mathrm{F}-85$ & 3 & WE-1 & $2 / 28 / 2009$ & $\mathrm{n}$ & $165 " \mathrm{~L} \times 161 / 2 " \mathrm{~W}$ \\
\hline$\underline{1019290}$ & $\mathrm{USA} / 9290 / \mathrm{B}(\mathrm{U})-85$ & 3 & F-430/GC-40 TRANSPORT PACKAGE & $2 / 28 / 2007$ & $\mathrm{n}$ & 36"H 35" D \\
\hline 1019291 & USA/9291/B(U)F-96 & 5 & $\begin{array}{l}\text { LIQUI-RAD (LR) TRANSPORT UNIT } \\
\text { PACKAGE }\end{array}$ & $10 / 31 / 2006$ & $\mathrm{n}$ & $56 " \mathrm{~L}$ x 56"W x 73"H \\
\hline $1019291 \mathrm{~B}$ & USA/9291/B(U)F-85 & 4 & $\begin{array}{l}\text { ECO-PAK LIQUI-RAD (LR) TRANSPORT } \\
\text { UNIT PACKAGE (EXPIRATION EXTENDED } \\
\text { BY REVISION } 5 \text { TO 3/31/2007) }\end{array}$ & $10 / 31 / 2006$ & $\mathrm{n}$ & $\begin{array}{c}56 " \mathrm{~L} \times 56 " \mathrm{~W} \times 73 " \mathrm{H} \\
(5692 \mathrm{lbs})\end{array}$ \\
\hline 1019293 & USA/9293/B(U)F-85 & 2 & TN-68 TRANSPORT PACKAGE & $2 / 28 / 2011$ & $\mathrm{n}$ & $\begin{array}{c}\text { 69"D x 178"L } \\
(686 " \times 6 " \text { cells }) \\
\end{array}$ \\
\hline$\underline{1019295}$ & $\mathrm{USA} / 9295 / \mathrm{B}(\mathrm{U}) \mathrm{F}-96$ & 0 & MFFP & $6 / 30 / 2010$ & $\mathrm{n}$ & $30 " \times 171 " \mathrm{OD}$ \\
\hline 1019296 & USA/9296/B(U)-96 & 5 & 880 SERIES PACKAGES & $3 / 31 / 2011$ & $\mathrm{n}$ & 5" D 13 5/6"L \\
\hline 1019299 & USA/9299/B(U)-85 & 1 & $\begin{array}{l}\text { F-423 } \\
\text { overpack w/no shielding }\end{array}$ & $8 / 31 / 2006$ & $\mathrm{n}$ & $60 " \mathrm{~L}$ x $40 " \mathrm{~W}$ x $58 \mathrm{H}$ \\
\hline 1019302 & USA/9302/B(U)F-85 & 1 & $\begin{array}{l}\text { NUHOMS }{ }^{\circledR} \text {-MP197 } \\
(3.25 " \mathrm{~Pb} \text { shielding }) \\
\end{array}$ & $7 / 31 / 2007$ & $\mathrm{y}$ & $\begin{array}{c}208 \times 91 \\
(149,000 \mathrm{lbs}) \\
\end{array}$ \\
\hline$\underline{1019309}$ & USA/9309/B(U)F-96 & 6 & RAJ-II & $11 / 30 / 2009$ & $\mathrm{n}$ & $\begin{array}{c}184.49 " \mathrm{~L} \mathrm{x} 18.07 " \mathrm{~W} \text { x } \\
11.26 " \mathrm{H} \\
\end{array}$ \\
\hline$\underline{1019310}$ & $\mathrm{USA} / 9310 / \mathrm{B}(\mathrm{U})-96$ & 2 & F-431 TRANSPORT PACKAGE & $6 / 30 / 2009$ & $\mathrm{n}$ & $32 " \mathrm{H} 22 " \mathrm{D}$ \\
\hline$\underline{1019314}$ & USA/9314/B(U)-96 & 2 & 976 SERIES & $6 / 30 / 2010$ & $\mathrm{n}$ & 21 1/4H $193 / 4 " \mathrm{D}$ \\
\hline$\underline{\underline{1019315}}$ & USA/9315/B(U)F-96 & 0 & ES-3100 & $4 / 30 / 2011$ & $\mathrm{n}$ & $32 " \mathrm{H} \times 5 " \mathrm{D}$ \\
\hline 1019511 & $\mathrm{USA} / 9511 / \mathrm{B}(\mathrm{U})$ & 3 & BUSS R-1 & $7 / 31 / 2007$ & & $23 " \mathrm{H} \times 20.25 " \mathrm{D}$ \\
\hline & $\mathrm{USA} / 5607 / \mathrm{B}() \mathrm{F}$ & 12 & $\mathrm{~T} 2$ & $10 / 1 / 2008$ & $\mathrm{n}$ & $6.065 " \mathrm{D} 100 " \mathrm{~L}$ \\
\hline
\end{tabular}


Table B-3. Department of Energy Certificates of Compliance.

\begin{tabular}{|c|c|c|c|c|c|c|}
\hline \multicolumn{5}{|c|}{ DOE Certificates of Compliance } & \multirow[b]{2}{*}{$\begin{array}{c}\text { Usable for } \\
\text { Vols. of } \\
\text { Activated Metal } \\
\end{array}$} & \multirow[b]{2}{*}{$\begin{array}{l}\text { Cavity H" x Dia" and } \\
\text { Cask Gross Weight } \\
\end{array}$} \\
\hline $\begin{array}{l}\text { Retrieval } \\
\text { Number }\end{array}$ & Package ID Number & Rev & Package Model Number & $\begin{array}{l}\text { Expiration } \\
\text { Date }\end{array}$ & & \\
\hline 1015607 & USA/5607/B( )F & 12 & T-2 & $10 / 1 / 2008$ & $\mathrm{n}$ & $6 " \times 100 "$ \\
\hline 1025320 & USA/5320/B(M)F-85 (DOE) & 0 & \begin{tabular}{|l|}
5320 - For a copy of this CoC, contact Dirk \\
Cairns-Gallimore, NE-50, at (301) 903- \\
$3332^{\text {a }}$ \\
\end{tabular} & $4 / 30 / 2011$ & $\mathrm{n}$ & $20 "$ x $60 "$ \\
\hline 1025320B & USA/5320-3/B( )F (DOE) & 23 & $\begin{array}{l}5320 \text { - For a copy of this CoC, contact Dirk } \\
\text { Cairns-Gallimore, NE-50, at (301) 903- } \\
3332^{\text {a }}\end{array}$ & $10 / 1 / 2008$ & $\mathrm{n}$ & $20 "$ x $60 "$ \\
\hline$\underline{1026058}$ & USA/6058/B( )F (DOE) & 4 & B-3 & $10 / 1 / 2008$ & $\mathrm{n}$ & 43 1/4"H; 26 1/2"D \\
\hline$\underline{1029098}$ & USA/9098/B( ) (DOE) & 2 & CI-20WC-2 AND CI-20WC-2A & $10 / 1 / 2008$ & $\mathrm{n}$ & $2.73 " \mathrm{OD} \times 5.56 " \mathrm{~L}$ \\
\hline$\underline{1029132}$ & USA/9132/B(M)F (DOE) & 11 & $\mathrm{~T}-3$ & $8 / 31 / 2009$ & $\mathrm{n}$ & $8.625 " \mathrm{D}$ \\
\hline$\underline{1029225}$ & USA/9225/B(U)-85 (DOE) & 3 & NAC-LWT & $12 / 31 / 2006$ & $\mathrm{n}$ & 178"L x 13.4" D \\
\hline$\underline{1029511}$ & USA/9511/B(U)-85 (DOE) & 7 & $\begin{array}{l}\text { BENEFICIAL USES SHIPPING SYSTEM } \\
\text { CASK (BUSS) MODEL R-1 }\end{array}$ & $3 / 31 / 2008$ & $\mathrm{n}$ & 23"H 20.25" D \\
\hline 1029516 & USA/9516/B(U)F-85 (DOE) & 11 & $\begin{array}{l}\text { MOUND 1KW - For a copy of this CoC, } \\
\text { contact Dirk Cairns-Gallimore, NE-50, at } \\
\text { (301) } 903-3332^{\mathrm{a}}\end{array}$ & $2 / 28 / 2011$ & $\mathrm{n}$ & $20 "$ x $60 "$ \\
\hline$\underline{1029519}$ & USA/9519/B(U)-96 (DOE) & 0 & SAFESHIELD 2999A & $10 / 31 / 2010$ & $\mathrm{n}$ & 54.96"H x 40.94"D \\
\hline 1029904 & USA/9904/B(U)F-85 (DOE) & 11 & $\begin{array}{l}\text { RTG PACKAGE - For a copy of this CoC, } \\
\text { contact Dirk Cairns-Gallimore, NE-50, at } \\
(301) 903-3332^{\text {a }}\end{array}$ & $2 / 28 / 2011$ & $\mathrm{n}$ & $20 "$ x $60 "$ \\
\hline 1029932 & USA/9932/B(U) (DOE) & 9 & UC-609 & 2/28/2009 & $\mathrm{n}$ & 44.06"L 18" D \\
\hline$\underline{1029975}$ & USA/9975/B(M)F-85 (DOE) & 16 & 9975 & $3 / 31 / 2011$ & $\mathrm{n}$ & $\begin{array}{l}\text { 24"L (within 35- } \\
\text { gallon drum) }\end{array}$ \\
\hline
\end{tabular}

Table B-4. Truck-loaded casks viable by volume and assessed by weight.

\begin{tabular}{|c|c|c|c|c|c|c|}
\hline $\begin{array}{c}\text { Type B } \\
\text { Cask }\end{array}$ & $\begin{array}{c}\mathrm{Pb} \\
\text { Shielding } \\
\text { (in.) }\end{array}$ & $\begin{array}{l}\text { Attenuation } \\
\text { Value } \\
(\mathrm{R} / \mathrm{h})\end{array}$ & $\begin{array}{c}\text { Cavity Size } \\
\mathrm{h} \times \mathrm{d} \\
\text { (in.) }\end{array}$ & $\begin{array}{c}\text { Gross } \\
\text { Weight } \\
\text { (lb) }\end{array}$ & Viable & Assessment Result \\
\hline CNS 3-55 & 6 & 15,000 & $111 \times 36$ & $70 \mathrm{~K}$ & Yes & Potentially Viable \\
\hline FSV-1 & 7.5 & 15,000 & $187 \times 17$ & $42.3 \mathrm{~K}$ & No & $\begin{array}{c}\text { Excluded } \\
\text { (volume and } \\
\text { C of C 4/19/06) }\end{array}$ \\
\hline TN-RAM & 5.88 & 15,000 & $111 \times 35$ & $80 \mathrm{~K}$ & Yes & Potentially Viable \\
\hline
\end{tabular}


The potentially viable casks, based on cavity dimensions, weight, shielding, transportation method (highway), and C of C status, were further evaluated for viability, and the details are shown as follows:

- Further evaluation of the Duratek CNS 3-55 cask indicated that the cask is not viable because the C of $\mathrm{C}$ expired in October 1, 2008. The cask is not renewable per the DOE Office of Transportation bulletin and more cannot be fabricated. However, Duratek, which has since merged with EnergySolutions, was in the design phase of developing a new cask to replace the CNS 3-55. Specifications of cask design presented in an August 25, 2005, presubmittal meeting presentation to the NRC, indicated that the replacement cask, the 3-60B cask, would meet the criteria for shipment of the remote-handled LLW activated metal waste offsite. The shielding and cavity dimensions are adequate and the cask is being designed to a $3000 \times \mathrm{A} 2$ criteria. A public meeting to present the 3-60B has been schedule by NRC for October 13, 2009.

- When cask evaluation was initiated in 2006, the TN-RAM truck-loaded cask also was considered potentially viable, and it was assumed that the $\mathrm{C}$ of $\mathrm{C}$ could be extended (see DOE Office of Transportation bulletin). However, at the time of the evaluation, only one TN-RAM was in existence and it was exclusively contracted to SWE Nukem for use in the commercial nuclear industry. The cask had not been allowed to be fabricated since 1999. It was determined, however, that the design could be reviewed against current criteria to obtain a new $\mathrm{C}$ of $\mathrm{C}$ since its design could accommodate transport of waste. Transnuclear holds the $\mathrm{C}$ of $\mathrm{C}$ and was assessing the feasibility of submitting this assessed design to NRC. This vendor needed a lead time of 3 years for the $\mathrm{C}$ of $\mathrm{C}$ approval and was concerned that they would not be able to deliver the required number of casks by the September 30, 2011, deadline (used for planning purposes of 2006) for beginning offsite shipment of activated metals. C of C No. 9233, Rev. 9, for the Model No. TN-RAM Package, under a February 23, 2009, cover letter, has since been issued, which may now provide the needed capability and authorize construction.

While, at the start of the study, there were no casks for waste transport available that fit the needs of the INL Site for remote-handled LLW activated metals, now at least one viable truck-loaded commercial cask is available (EnergySolutions' 3-60B) and possibly a second (Transnuclear's TN-RAM). It is reasonable to conclude that there will be a commercial truck-loaded cask available for offsite shipment of remote-handled LLW activated metals. A \$2M/cask unit cost is appropriate for purposes of cost estimating based on communication with the vendors. It also should be assumed that casks can be available within 24 months of procurement. 


\section{Appendix C}

\section{Assumptions, Schedules, Costs}




$$
\text { C-2 }
$$




\section{Appendix C Assumptions, Schedules, Costs}

This appendix provides cost and schedule information for the remote-handled LLW disposal scenarios. For each scenario, the following information is presented:

- A summary of total costs, including the basis of estimate

- Annual total, operating, and capital costs for the scenario

- A schedule. 


\section{Appendix C-1 \\ Onsite Disposal of \\ Remote-Handled Low-Level Waste}

\begin{tabular}{llr}
\hline \multicolumn{1}{c}{ Activities } & Cost \\
\hline 1. & Approve mission need/cost range & $\$ 1,785,083$ \\
& CD-2/CD-3, Approve Mission Performance Baseline/Execute Design- & \\
2. & Build & $\$ 53,458,464$ \\
3. CD-4, Approve Start of Operations & $\$ 2,498,539$ \\
4. & Operations & $\$ 119,016,855$ \\
5. Closure activities & $\$ 14,003,266$ \\
\hline & & $\$ 190,762,207$ \\
\hline
\end{tabular}

\section{C-1.1. Basis of Estimate}

Costs for this alternative are based on the following:

1. "Remote-Handled Low-Level Waste Disposal Project Documentation, Construction, and Start-up," Cost Estimate \#9A28-G, T.L. Julius, B.W. Wallace (September 2009)

2. "Remote-Handled Low Level Waste Disposal Project Operations, Disposal and Close-Out Activities FY 2016 - FY 2035," Cost Estimate\#9A28-H1, J.R. Baker, T.L. Julius (October 2009)

3. Operational and vault design costs taken from the SDA

4. Adjusted landfill costs from ICDF design and construction

5. Facility closure estimates adjusted from EDF-2385, "INEEL CERCLA Disposal Facility Onsite versus Offsite Cost Comparison."

\section{C-1.2. Management Reserve Analysis}

Each cost estimate prepared to support this scenario applied a management reserve. The average management reserve for the scenario is $30 \%$. Management reserve addresses the following uncertainties:

1. This is a pre-conceptual design estimate

2. The relative remote nature of the facility

3. The actual facility site has not been selected 
4. Materials, charging practices, rates, and labor costs cannot be projected accurately over the 26-year time span

5. Regulatory and political uncertainty

6. The costing system that provided historical costs does not differentiate costs to a level of detail necessary to ensure all costs were captured

7. Any mathematical differences are a result of rounding numbers between programs.

\section{C-1.3. Specific Assumptions}

1. Post closure monitoring and surveillance costs are assumed to be absorbed into overall site long-term stewardship costs for INL (assumed by the Office of Legacy Management).

2. The estimate is based on construction of a disposal cell in line with current industry engineering design practices for LLW disposal. 


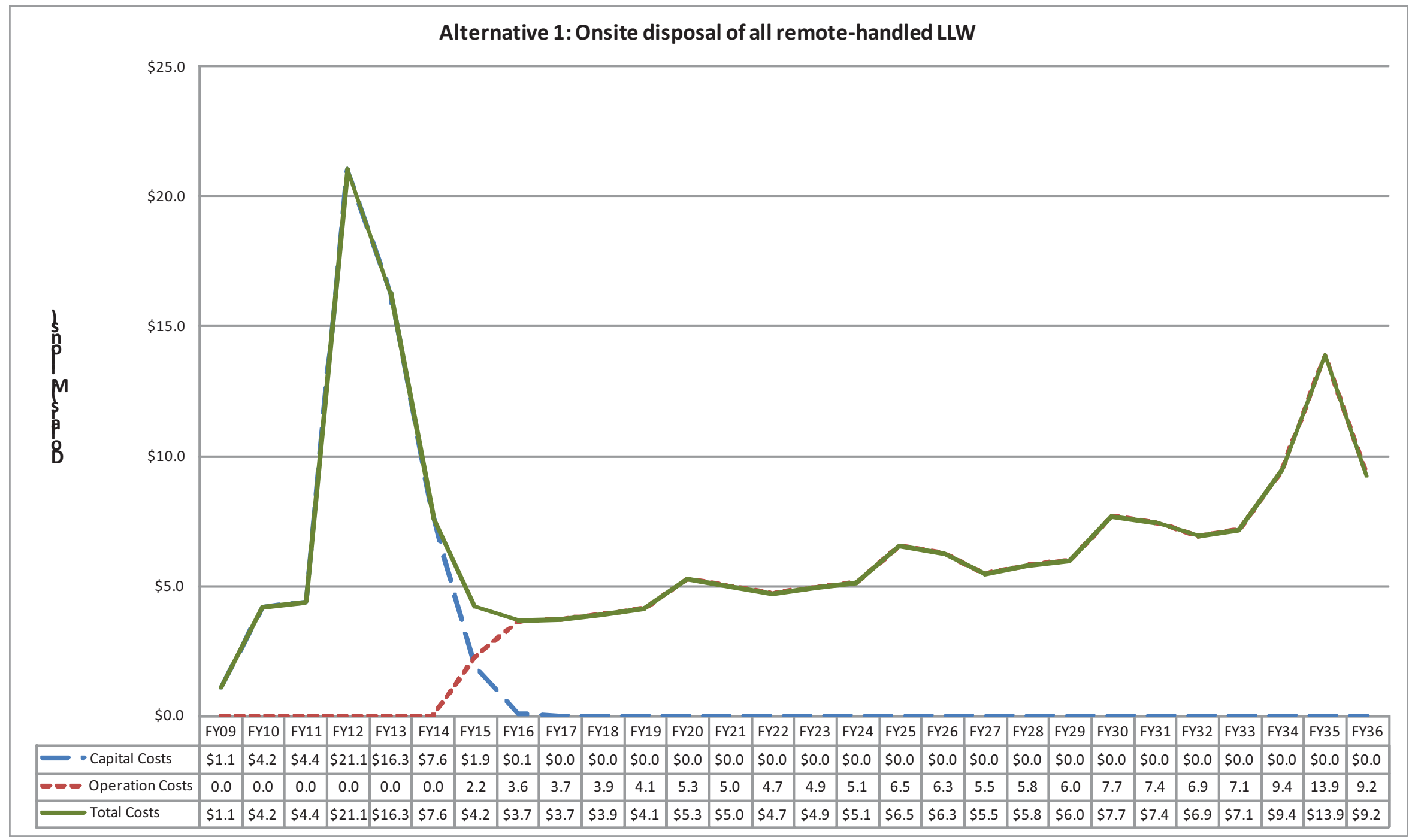

Figure C-1.1. Costs for onsite alternative. 


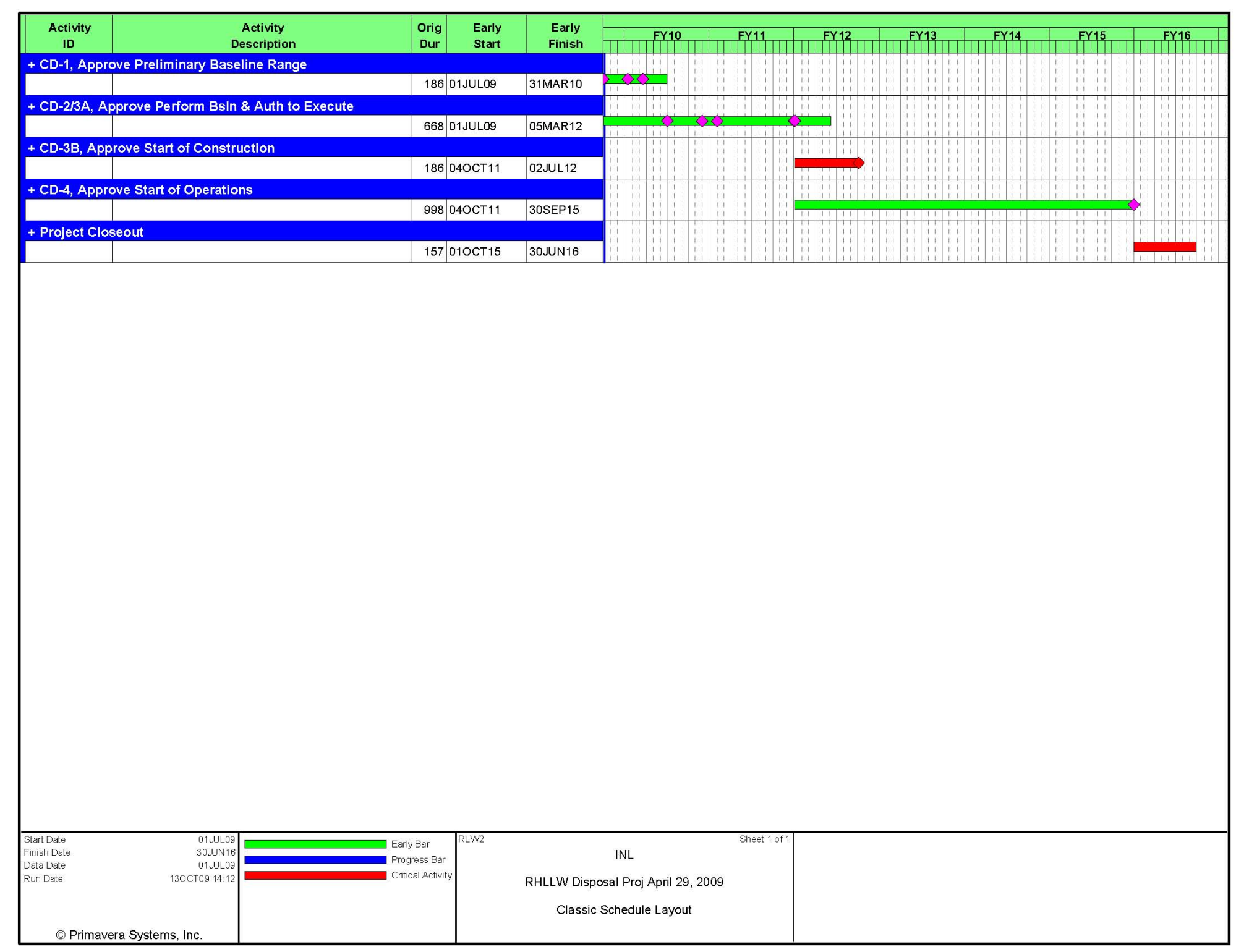

Figure C-1.2. Schedule for onsite alternative. 


\section{Appendix C-2}

\section{Disposal of Remote-Handled Low-Level Waste Offsite at the Nevada Test Site}

\begin{tabular}{llr}
\hline & \multicolumn{1}{c}{ Activities } & \multicolumn{1}{c}{ Cost } \\
\hline 1. & Cask procurement and infrastructure development & $\$ 31,641,623$ \\
2. & Activated metals to NTS (Ops) & $\$ 535,472,783$ \\
3. & Offsite disposal of resins & $\$ 30,520,283$ \\
\hline \multicolumn{2}{l}{ Total Cost } & $\$ 597,634,689$ \\
\hline
\end{tabular}

\section{C-2.1 Basis of Estimate}

Costs for this alternative are based on the following:

1. “Truck Transported RH-LLW Shipping Cask Development, Testing \& Approval,” Cost Estimate \#MA34, T. L, Julius (October 2009)

2. "RH LLW - Packaging, Transportation, and Disposal of Truck Transported Cask at NTS," Cost Estimate \#MA33, T. L. Julius (October 2009)

3. "RH LLW ATR Resins - LSA Package - Type A Shielded Container to NTS," Cost Estimate \#M22A, R.R. Honsinger, T.L. Julius (October 2009).

\section{C-2.2 Management Reserve Analysis}

Each cost estimate prepared to support this scenario applied a management reserve. The average management reserve for the scenario is $30 \%$. Management reserve addresses the following uncertainties:

1. Materials, charging practices, rates, and labor costs cannot be projected accurately over the 26-year time span

2. Regulatory and political uncertainty

3. The costing system that provided historical costs does not differentiate costs to a level of detail necessary to ensure all costs were captured

4. Some activities may have been missed, which could result in significant cost impacts when escalated over the life of the project (through FY 2035).

\section{C-2.3 Specific Assumptions}

1. NTS will continue to be a viable disposal path throughout the duration of this project.

2. Capital funding will be available to support acquisition of shipping casks by the end of FY 2015. 


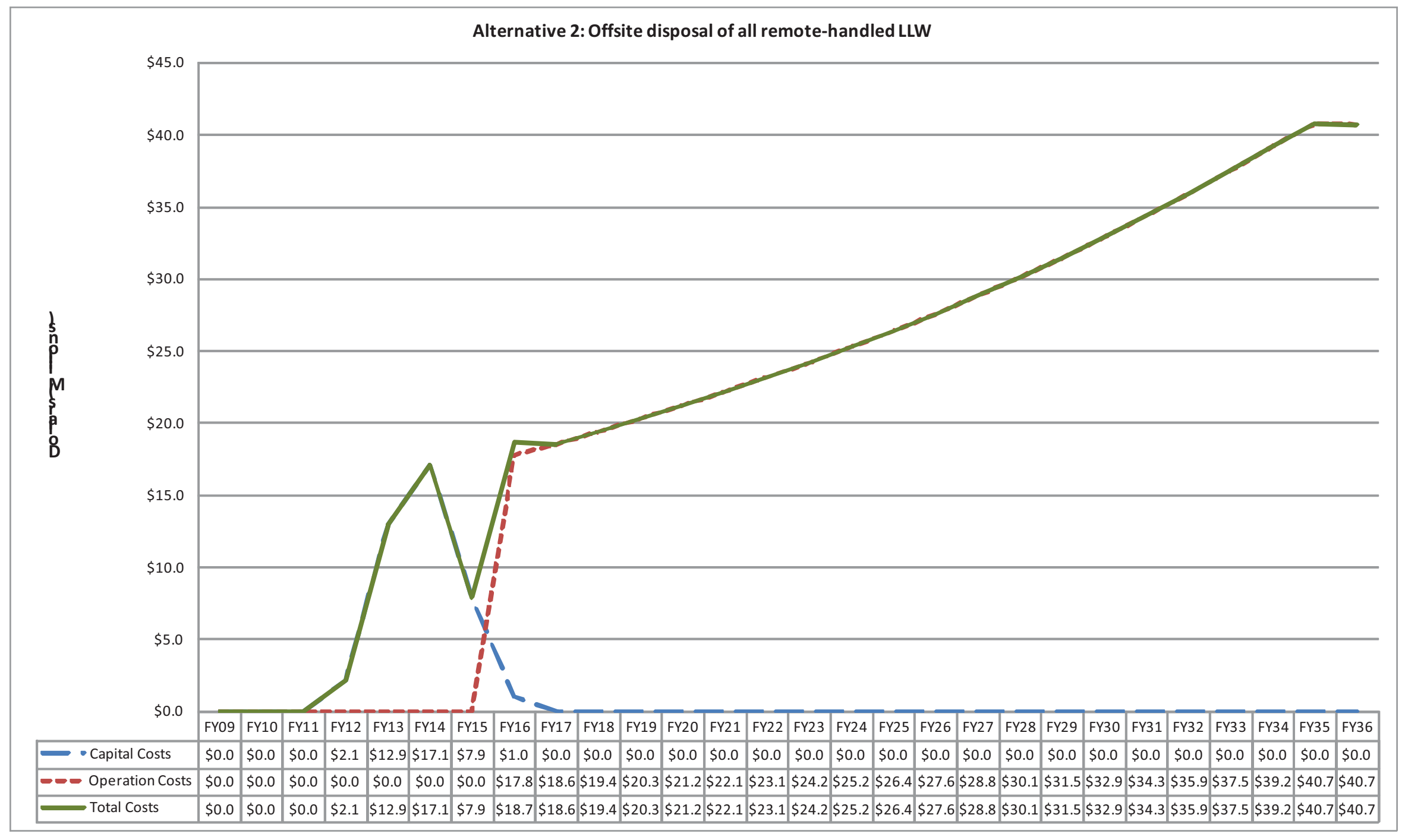

Figure C-2.1. Costs for the offsite disposal at the Nevada Test Site alternative. 


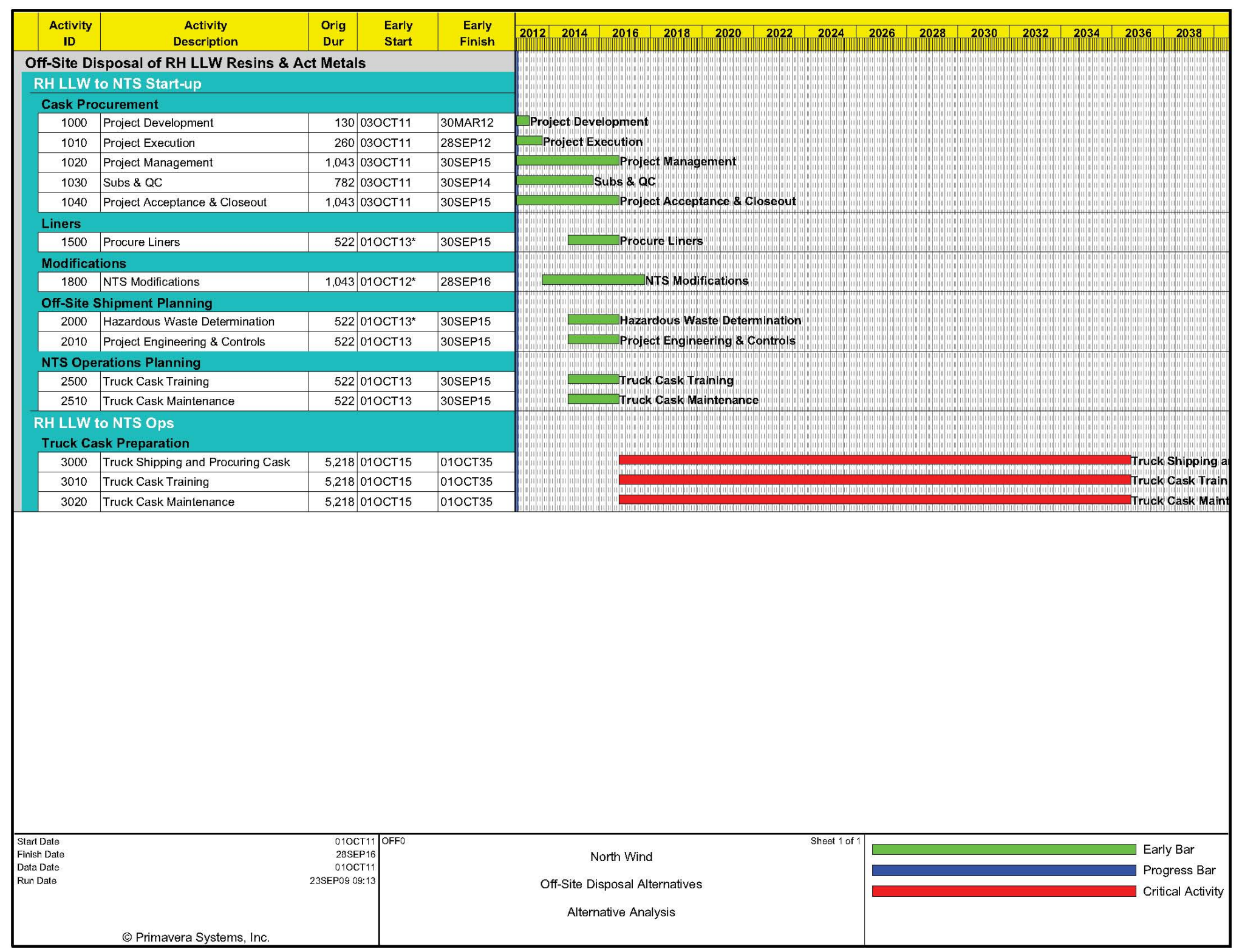

Figure C-2.2. Schedule for the offsite disposal at the Nevada Test Site alternative. 